\title{
"RELIGION AS AN ENGINE OF CIVIL POLICY": A COMMENT ON THE FIRST AMENDMENT LIMITATIONS ON THE CHURCH-STATE PARTNERSHIP IN THE SOCIAL WELFARE FIELD
}

\author{
Thomas W. Pickrell* and Mitchell A. Horwich $\dagger+\frac{\ddagger}{\ddagger}$
}

\section{INTRODUCTION}

James Madison warned in his famous Memorial and Remonstrance Against Religious Assessments that to use tax revenues to finance teachers of the Christian Religion is to "employ Religion as an engine of Civil policy." Such a tax assessment would of course violate the Establishment Clause of the first amendment. ${ }^{2}$ Congress cannot prescribe religious education for the ills of society. But the federal and state governments can employ religiously motivated persons and institutions to carry out governmental functions. As Chief Justice Warren stated in McGowan v. Maryland, ${ }^{3}$ government action is not banned under the first amendment merely because it "happens to coincide or harmonize with the tenets of some or all religions." 4 The many Church-State partnerships in the social service field are based upon this fortunate harmonization of governmental and religious purposes. Chief Justice Warren's statement answers one question yet creates another, perhaps more important, one. Governmental and religious purposes may validly coincide, but at what point does this harmonization of purpose become subsidization of religious activity in effect? Supreme Court cases since $M c$ Gowan give answers to this question.

In three sections, this paper will analyze the first amendment limitations on the Church-State partnership in the social services field. In the first section, the past and present role of the $\mathrm{Church}^{5}$ as a social service provider will be summarized. In the second section, the Religion Clauses will be analyzed to determine what constitutional restrictions are imposed upon the Church and State when they deal with

Copyright (C) 1981 by Duke University

* Duke University School of Law, class of 1982

$\uparrow$ Duke University School of Law, class of 1982

\$ The editorial assistance of Dr. Joyce Rutledge and Jay Whitehurst is gratefully acknowledged. We wish to thank especially Professors William W. Van Alstyne and Thomas D. Rowe, Jr. for their thoughtful commentary on earlier drafts of this paper.

1. J. Madison, Memorial and Remonstrance Against Religious Assessments (1784) printed in its entirety in Everson v. Board of Educ., 330 U.S. 1, 63-72 (1947).

2. Everson v. Board of Educ., 330 U.S. 1, 16 (1947).

3. 366 U.S. 420 (1961).

4. McGowan v. Maryland, 366 U.S. at 442.

5. The term "Church" in this article will refer collectively to all institutions with an active religious affiliation. 
each other as partners. In the third section, this analysis will be applied specifically to the current practice of state support of religious institutions providing hospital and adoption services. In different ways, each service illustrates the first amendment limitations imposed upon the State and the Church when the latter participates in a social welfare program.

\section{The Church in the Social Welfare Field}

The care of the indigent, the neglected, and the sick by religious organizations derives from a fundamental theological commitment to charity and "good works." 6 Religious groups traditionally have worked to meet community welfare needs of every type, often with more sensitivity than public welfare agencies. ${ }^{7}$ The harmonization of the church's humanitarian ideals with the government's public responsibility for social welfare is the foundation for the modern Church-State partnership in social welfare programs. Currently the Church participates in a wide variety of social welfare programs funded by federal and state governments. A brief history of the Church as a social welfare provider helps to explain the relationship between Church and State which now exists in the social welfare field. ${ }^{8}$

Until the turn of the century, local private religious and charitable organizations provided most of the relatively few social welfare services then available in this country. ${ }^{9}$ Welfare services on a greater scale were required, however, with the advent of industrialization and the arrival of impoverished immigrants in the major urban areas. ${ }^{10}$ As the cost of services began to exceed the available funds of the private charities, state and local governments began to subsidize these efforts of private welfare groups and to establish their own welfare agencies. ${ }^{11}$ This relationship between the Church and local governments has continued to the present day,

6. B. Coughlin, Church and State in Social Welfare 15-43 (1965); Interfaith Research Committee, A Study of Religious Receipts and Expenditures in the United States in 1 ResearCH PAPERS 365, 369 (Comm'n on Private Philanthropy and Public Needs ed. 1977). See also Contemporary Religion and Social Responsibility (N. Brockman \& N. Piediscalzi eds. 1973).

7. I. Leiby, A History of Social Welfare and Social Work in the United States 75-89 (1978); J. Pratt, Religion, Politics, and Diversity: The Church-State Theme in New York HistoRY 205-24 (1967).

8. On the history of church involvement and the relations between Church and State in the social welfare field see generally Coughlin, supra note 6; L. Pfeffer, Church, State, and Freedom 196-205 (rev. ed. 1967); Bremner, Private Philanthropy and Public Needs: Historical Perspective in 1 Research Papers 89 (Comm'n on Private Philanthropy and Public Needs ed. 1977); Guilfoyle, Church-State Relations in Welfare, 3 CATH. LAW. 112 (1957).

9. Social welfare services were generally limited to hospital services for the sick or mentally ill and adoption services. Families might also look to private charities for subsistence funds during an emergency. See generally Leiby, supra note 7 , at 71-89, $111-120$; W. TrattNer, From Poor Law To Welfare STATE 80-93 (1974).

10. See H. Wilensky \& C. Lebeaux, Industrial Society and Social Welfare 168-228 (1958).

11. See LeibY, supra note 7 , at 90-101, 151-54; TrattNer, supra note 9, at $179-87$ (1974). Cases from the federal and state courts also illustrate this development. See, e.g., Bradfield v. Roberts, 175 U.S. 291 (1899) (taxpayer challenge of financial assistance to Catholic hospital); Dunn v. Chicago Indus. School, 280 Ill. 613,117 N.E. 735 (1917) (upholding appropriation to private institution housing wards of the state). 
becoming more extensive as state and local governments increase the size and sophistication of their social welfare programs.

During the 1930s, the federal government stepped in to provide the services and benefits required to meet the tremendous welfare needs caused by the Great Depression. The federal relief programs organized under the "New Deal" were the federal government's first major plunge into the social welfare field. ${ }^{12}$ These programs were purportedly based upon an important concept: the right of the individual, as a citizen, to welfare benefits regardless of the willingness or financial ability of the private sector to provide them. ${ }^{13}$ Consequently, these programs were implemented independently of the private charities; federal relief programs stipulated that federal assistance could be distributed only by public agencies. ${ }^{14} \mathrm{Al}$ though Church-State partnerships were maintained on the local level, private welfare groups generally did not participate in the new federal welfare system of this period.

After the 1930s, however, religious organizations began to receive federal funds. At the close of World War II, the federal government began to subsidize social welfare services which previously were the concern solely of state and local governments. For example, the Hill-Burton program ${ }^{15}$ was initiated to raise the nation's standard of medical care by subsidizing the costs of local public and private hospital construction. In each of the programs, the financial design is similar: federal funds are channeled through state and local governments where collectively federal, state, and local funds are distributed to the public and private agencies providing services. Today, religious organizations participate in a variety of programs within this same state and federal financing system. ${ }^{16}$ Religious groups may

12. These federal relief programs are discussed generally in LEIBY, supra note 7, at 217-244.

13. The director of federal relief programs, Harry Hopkins, wanted to avoid dependence on the willingness or availability of private groups. His policy that federal dollars be distributed by public agencies created a new bureaucracy to administer relief and started the broad federal involvement in the social welfare field that continues to the present. See LEIBY, supra note 7, at 224-30; TRATTNER, supra note 9 , at $236-37$.

14. Id.

15. The full title of the Hill-Burton Act is the Hospital Survey and Construction Act of 1946, 42 U.S.C. $\$ \S 291-2910-1$ (1976).

16. See, e.g., 42 U.S.C. $\$ 622$ (Supp. 1978) as amended by Pub. L. 96-272, 94 Stat. 516 (1980) (Title IV-B of Child Welfare Services); 42 U.S.C. $\$ \S 630-644$ (1976) (Work Incentive Program) (as implemented according to 45 C.F.R. $\$ 224.30(\mathrm{c})(1)$ (1980)); 42 U.S.C. $\S 1397$ a (1976) (Title XX Day Care Services under Social Security Act); 42 U.S.C. $\$ \S 2931-2932$ (1976) (Head Start); Disaster Relief Act of 1974. Pub. L. No. 93-288, $\S 312,88$ Stat. 143 (1974); Juvenile Delinquency Prevention and Control Act of 1968, Pub. L. No. 90-445, $\S 102,82$ Stat. 462 (1968); Social Security Amendment of 1967, Pub. L. No. $90-248$, $\S 301,81$ Stat. 821 (1968) (amending Title $V$ of the Social Security Act, Maternal and Child Health and Crippled Children's Services); Housing Act of 1961, Pub. L. No. 87-70, $\$ 101,75$ Stat. 149 (1961) (amending National Housing Act $\S 221$ (d)(3)); Housing Act of 1959, Pub. L. No. 86-372, § 202, 73 Stat. 654 (1969); Pfeffer, supra note 8, at 202-05 (on Church involvement in the Economic Opportunity Act of 1964, Pub. L. No. 88-452, 78 Stat. 508 (1964) and the Peace Corps Act of 1961, Pub. L. No. 87.293, 78 Stat. 612 (1961)); Sullivan, The Politics of Altruism: The American Church-State Conflict in the Food-for-Peace Program, $11 \mathrm{~J}$. OF CHURCH \& ST. 47 (1969) (on church involvement in the Agricultural Act of 1949, Ch. 792, 63 Stat. 1051 (1949)). See also Bill to Provide for Judicial Review of the Constitutionality of Grants or Loans Under Certain Acts: Hearings on S.2097 Before the Subcomm. on Constitutional Rights of the Senate Judiciary Comm., 89th Cong., 2d Sess. 699-716 (1968) (summary of federal programs under which religious organizations may receive assistance). See text accompanying notes 93-98 infra, on Church involvement in the Hill-Burton program. 
receive government funds by direct grant or subsidy, but more often they are reimbursed under purchase of service contracts with government agencies. ${ }^{17}$ Religious organizations still contribute large sums of their own money to welfare efforts, ${ }^{18}$ but the federal and state governments remain the dominant force in the financing and operation of social welfare services.

The Church-State partnership is not without its problems, however. First, government funds invariably bring with them regulations forcing religious organizations to conform to standards which may conflict with the organization's religious values or interfere with its religious exercise. Many religious groups feel that government regulation intrudes to the point of infringement upon their free exercise rights. ${ }^{19}$ Second, the steady growth of the public sector in the social welfare field raises concern for the continued viability of the private charities. Government involvement may have the effect of extinguishing the "voluntarism" which is the lifeblood of a privately-funded organization and "squeezing" the private charities from the social service field. ${ }^{20}$

The existence of the current Church-State partnership, its problems, and the available solutions to those problems are dependent upon the effect of the Religion Clauses of the first amendment. When the government can, cannot, or perhaps, must use a religious institution to perform a particular welfare service is ultimately limited by the Establishment and Free Exercise Clauses. Yet conflict may arise between these two clauses. As Justice Rehnquist observed, "the growth of social welfare legislation during the latter part of the 20th Century has greatly magnified the potential for conflict between the two clauses since legislation touches the

17. See Cohen, Some Aspects of Evolving Social Policy in Relation to Private Philanthropy in 2 RESEARCH Papers 657 (Comm'n on Private Philanthropy and Public Needs ed. 1977). A purchase of services contract is an agreement between a government social service agency and a private organization to reimburse the private organization for services it provides to an individual or family who is eligible to receive government services.

18. See Interfaith Research Committee, supra note 6, at 378-79.

19. The two cases involving the revocation of forms of government financial assistance to Bob Jones University because of the university's religiously inspired policies of racial segregation illustrate this problem. See Bob Jones University v. United States, 639 F.2d 147 (4th Cir. 1980) (affirming government authority to revoke tax-exempt status); Bob Jones University v. Roudebush, 529 F.2d 514 (4th Cir. 1975) (per curiam), aff'g, Bob Jones University v. Johnson, 396 F. Supp. 597 (D.S.C. 1974). See also Kelly, Confronting the Danger of the Moment 9, 13-14 in Church, State and Public Policy (J. Mechling ed. 1978); Kirk, Shelton College and State Licensing of Religious Schools: An Educator's View of the Interface between the Establishment and Free Exercise Clauses, 44:2 L. \& ConteMP. ProB. 169 (1981).

20. Gianella, Religious Liberty, Nonestablishment, and Doctrinal Development; Part II, the Nonestablishment Principle, 81 HaRv. L. Rev., 513, 522-26 (1968). Cf. Coughlin, supra note 6, at $111-16$ (presents the attitudes and policies of various religious groups concerning the growth of government and the secularization of welfare institutions); Schwartz, The Nonestablishment Principle: A Reply to Professor Gianella, 81 HaRv. L. REv. 1465, 1468-70 (1968) (questioning the validity of Professor Gianella's economic assumptions). See P. Berger \& R. Neuhaus, To Empower People: The Role of Mediating Structures IN Public Policy (1977); Kerrine \& Neuhaus, Mediating Structures: A Paradigm for Democratic Pluralism, 446 Annals 10 (1979). These materials present a sociological critique of the tendency of the modern welfare state to undermine the traditional role of mediating structures such as the family and voluntary associations. The Church is discussed as one of these structures which bridges the gap between individual values and public purpose. The authors decry the trend toward eliminating the religious character of church involvement with the state and suggest various means by which religion may incorporated into public policy. See also Church, State, and Public Policy (J. Mechling ed. 1978). 
individual at so many points in his life."21 As the government expands into the social welfare field, an aspect of society once based upon the relationship between the Church and individual, first amendment problems are created. In the remaining two sections, the first amendment limitations upon this Church-State partnership will be explored.

II

The Church-State Partnership Under the Religion Clauses

As discussed in the previous section, the Church represents a substantial collection of public contractors. Church-State partnerships are generally based upon contractual principles; that is, the State makes conditional purchases of social services from the Church. The federal government, exercising its superior negotiating position, often stipulates that the contractor comply with regulations reflecting various social values desired by Congress. ${ }^{22}$ The Establishment Clause also regulates independently of the State or Church by imposing direct restraints upon the spending power of the government. ${ }^{23}$ The Establishment Clause is, in effect, a "third party negotiator" of any social service contract between the State and a religious institution.

This section will discuss generally the contours of the Establishment Clause so that the validity of various social service partnerships may be shown depending on where these contours are located. During the past decade, the Supreme Court has consistently applied a tripartite test to legislation challenged under the Establishment Clause: "First, the [social service program] must have a secular legislative purpose; second its principal or primary effect must be one that neither advances nor inhibits religion .. . finally, the [program] must not foster an excessive entanglement with religion." 24 The various Church-State partnerships will be considered in terms of the three requirements of the test. The section will then conclude with a discussion of the Church's free exercise rights once the social service partnership has been formed.

\section{A. Secular Legislative Purpose}

The tripartite test requires first that legislation serve a secular purpose. Accordingly, it would seem that legislation must not be undertaken for religious purposes. This is, of course, not the case. Legislation which happens to fulfill a religious purpose is permissible. For example, Sunday-closing laws which historically have a religious basis are valid because a secular purpose now also justifies their enactment. ${ }^{25}$ As well, legislation may be lobbied for by religiously motivated groups- even voted for by religiously motivated legislators-yet these various degrees of religious

21. Thomas v. Review Bd. Ind. Employment Security Div., 101 S. Ct. 1425, 1433 (1981) (Rehnquist, J., dissenting).

22. See, e.g., Title VI of the Civil Rights Act of 1964, $\$ 601$, codified at 42 U.S.C. $\S 2000 d$ (1976).

23. Flast v. Cohen, 392 U.S. 83 (1968).

24. Lemon v. Kurtzman, 403 U.S. 602, 612-13 (1971).

25. McGowan v. Maryland, 366 U.S. 420 (1961). 
purpose in the history of the legislation are insufficient to render it invalid. ${ }^{26}$ The Supreme Court clearly has a policy of deference to the legislature's collective statement of purpose for legislation. ${ }^{27}$ The point of invalidation apparently is reached when the Court finds that legislation could serve only a religious purpose. ${ }^{28}$ Consequently, if a cogent secular purpose is expressed, the Court will not interfere under the first requirement of the tripartite test.

One of the earliest first amendment cases, Bradfield $v$. Roberts, ${ }^{29}$ typifies the limited inquiry of the Supreme Court under the secular purpose requirement. In 1899, Providence Hospital, a charitable corporation operating under the auspices of the Catholic Church, received funds for hospital construction by congressional act. The Court found the hospital's religious affiliation "wholly immaterial." ${ }^{30}$ Instead, the Court focused upon the corporation's secular charter as proof that the funds would be used for a secular purpose. This finding of secular purpose in turn became the basis for validating the grant. By accepting the corporate charter's statement as sufficient evidence of secular purpose, the Court avoided any further substantive constitutional analysis. ${ }^{31}$

Complete reliance on secular purpose by the Bradfeld Court has of course given way to a more probing inquiry under the "primary effect" and "excessive entanglement" requirements of the modern Supreme Court. ${ }^{32}$ The danger of the Bradfield Court's analysis is clear: if, as in Bradfield, recitations of secular purpose alone could validate legislation, then the secular purpose requirement would become a mere technical requirement providing a safe harbor for substantive violations of the Establishment Clause. ${ }^{33}$ Secular legislative purpose, nonetheless, remains an initial inquiry. Secular purpose appears to be coextensive with the police powers of any legislature, ${ }^{34}$ and therefore, all social service partnerships, undertaken for public welfare purposes, comply with this initial requirement.

26. In Harris $v$ McRae, 448 U.S. 297 (1980), the Court held that the Hyde Amendment which prohibited the federal funding of not "medically necessary" abortions did not violate the Establishment Clause. The Hyde Amendment and other anti-abortion measures have received extensive political support from religiously motivated groups. See TIME, April 6, 1981, at 20, 26. Yet this consideration did not affect the Court's determination of the Amendment's secular purpose.

27. See Stone v. Graham, 101 S. Ct. 192, 195-96 (1980) (Rehnquist, J., dissenting).

28. A summary of Supreme Court decisions reveals that in only two decisions has the Court failed to honor a statement of secular purpose. See Stone v. Graham, 101 S. Ct. 192 (1980); Epperson v. Arkansas, 393 U.S. 97 (1968). The fact of religious motivation was so prevalent in each of these cases that a finding of secular purpose would have appeared disingenuous; thus invalidation was unavoidable.

29. 175 U.S. 291 (1899).

30. Id., at 299 .

31. See Abington School Dist. v. Schempp, 374 U.S. 203, 246 (1963) (Brennan, J., concurring).

32. Despite its limited inquiry, "secular purpose" remains the keystone of the tripartite test. With secular purpose established, the Court's inquiry under the second prong becomes whether that secular purpose is the "primary effect" of the legislation, and the inquiry under the third prong becomes whether the secular purpose is in danger of being converted to religious ends. Thus, a preliminary finding of secular purpose is essential to the analysis of the second and third requirements of the tripartite test.

33. Gillette v. United States, 401 U.S. 437, 450-54 (1971), is a modern illustration of the secular purpose requirement providing a safe harbor for Congress' efforts to protect religious interests. The Court found that the purpose of the military conscientious objector provision was secular despite its "religious beliefs" requirement because the provision reflected pragmatic military considerations and protected the value of conscience in democracy.

34. See, e.g., Everson v. Board of Educ., 330 U.S. 1, 7 (1947). 


\section{B. Primary Effect Which Neither Advances Nor Inhibits Religion}

The presence of an analysis which considers both the purpose and effect of legislation is evident as early as 1947, when the Court in Everson $v$. Board of Education $^{35}$ held that a state could reimburse parents for the cost of transporting their children to parochial schools on the public bus system. The Court confronted the fact that the program would promote both a secular end-safety of children-and a religious end-assistance to a school's religious mission-by subsidizing parents' transportation expenses. Finding the program neutral rather than adversarial to private, nonprofit schools, the Court gave tacit acceptance to indirect aid to religious schools as long as the activity funded is strictly secular. ${ }^{36}$

Holding the problem of indirect aid to religion in abeyance, ${ }^{37}$ Everson and subsequent decisions opened the door to programs which fund those services performed by religious institutions which can be characterized as secular. The central issue of the "primary effect" test became whether the secular services funded are truly separated or even separable from the religious aspects of the institution. ${ }^{38}$ This issue of separability has led the Court to formulate two categories of government assistance to religious institutions-education and general welfare services. $^{39}$ These categories are mutually exclusive, the latter being those services which are not intimately bound up in the education process.

The general welfare services category is based upon the Court's belief that these services, being neutral and nonideological, are clearly separable from the religious mission of the institution. ${ }^{40}$ The "primary effect" requirement, when applied to this category of services, is applied narrowly by focusing on the service itself. The secular purpose of the program is accepted by the Court as the primary effect of the program, and the benefit which accrues to the institution's religion is held to be permissibly incidental. The general welfare services category includes bus transportation, school lunches, public health services, and secular textbooks. ${ }^{41}$ This limited list, however, has been generated in the context of aid to schools otherwise

35. Id.

36. The Everson majority's resolution of the problem of aid to parochial schools permits indirect aid to religion. The dissent, led by Justice Rutledge, adopted a strict no-aid policy which has continued to influence several state supreme courts in the interpretation of their own state constitutions. Unlike the Federal Constitution, many state constitutions have provisions which directly prohibit aid to religious organizations. See C. Antieau, P. Carroll \& T. Burke, Religion Under the State Constitutions 1-2, 173-239 (1965). Those state supreme courts which have adopted the Rutledge dissent have interpreted their constitutions to preclude any form of aid to religious institutions. See, e.g., Matthews v. Quinton, 362 P.2d 932 (Alaska 1961); Dickman v. School Dist., 232 Or. 238, 366 P.2d 533 (1961). Social service contracts in such states would be barred under the state constitution, preempting any federal constitutional consideration on adequate state grounds. Other states have invoked liberal interpretations of such terms as "aid" and "religious purpose," thereby permitting various Church-State partnerships in the social welfare field. See Schade v. Allegheny County Inst. Dist., 386 Pa. 507, 126 A.2d 911 (1956); Community Council v. Jordan, 102 Ariz. 448, 432 P.2d 460 (1967); Abernathy v. City of Irvine, 355 S.W.2d 159 (Ky. 1961). cert. denied, 371 U.S. 831 (1962). In those instances, the state and federal constitutions impose the same limitations upon any social service contract.

37. See Roemer v. Maryland Pub. Works Bd., 426 U.S. 736, 746-47 (1976).

38. Tilton v. Richardson, 403 U.S. 672,680 (1971).

39. Wolman v. Walter, 433 U.S. $229,243-45$ (1977).

40. Lemon v. Kurtzman, 403 U.S. at 616-17; Wolman v. Walter, 433 U.S. at 243-45.

41. Lemon v. Kurtzman, 403 U.S. at 616-17. 
of a pervasively religious character. This category expands to encompass other more direct forms of assistance when the institution receiving the aid is not pervasively religious. For example, in Tilton $v$. Richardson, ${ }^{42}$ the Court validated construction grants for secular facilities in religiously affiliated universities. Finding the universities not pervasively religious and the grants neutral and nonideological, the Court held that assistance, like other general welfare services, had a secular effect that only incidentally supported the universities' religious mission. ${ }^{43}$ The general welfare services category, thus, appears to include all services other than those educational services which are themselves blended and mixed with pervasively religious institutions' ecclesiastical functions. Since many Church-State partnerships provide health or welfare services without any education service component, they will be included in this category. ${ }^{44}$

The education category is more problematic because education, necessarily a blend of the beliefs expressed by the institution's teachers and educational materials, may serve an ecclesiastical function. The Court apparently has adopted the position that even secular education is not fully separable from the religious mission of sectarian primary and secondary schools. ${ }^{45}$ Consequently, the Court applies a stricter standard of scrutiny to educational programs involving sectarian schools. The Court has consistently held that if the school is pervasively religious, the primary effect of funding any educational program within the school is to advance religion. ${ }^{46}$ This outcome forces the Court to disregard the term "primary effect," for the type of aid invalidated can be as neutral and nonideological as any general welfare service. Instead, the Court invokes a standard which invalidates all aid which is "direct and immediate" without determining the primary effect of the aid. ${ }^{47}$ For example, in Meek v. Pittenger, the Court held that direct aid in the form of educational materials such as maps, charts, and photographs to "Pennsylvania's predominantly church-related, nonpublic elementary and secondary schools, even though ostensibly limited to wholly neutral, secular instructional material and equipment, inescapably results in the direct and substantial advancement of religious activity. ..."48 The educational materials are clearly as neutral and nonideological as a secular textbook or a bus ride, but because they are given directly to the parochial school the assistance is invalid. The breadth of this category remains uncertain. ${ }^{49}$ It is limited to pervasively sectarian institutions, but does appear to

42. 403 U.S. 672 (1971)

43. The Court clearly analyzes the construction grant to religiously affiliated universities in terms of a general welfare service. See, e.g., Tilton v. Richardson, 403 U.S. at 679-82; Roemer v. Maryland Pub. Works Bd., 426 U.S. at 751 .

44. See Hospital Services, subsection A of Section III infra.

45. Meek v. Pittenger, 421 U.S. 349, 366 (1975); Lemon v. Kurtzman, 403 U.S. at 616-17, 657. Cf. Tilton v. Richardson, 403 U.S. at 681 (suggesting that the Court will not assume that the religiosity of parochial schools necessarily permeates the secular education provided).

46. Meek v. Pittenger, 421 U.S. at 366, Hunt v. McNair, 413 U.S. 734, 743 (1973).

47. Committee for Pub. Educ. v. Nyquist, 413 U.S. 756, 783-84 n.39 (1973).

48. Meek v. Pittenger, 421 U.S. at 366.

49. The education category, characterized by the "direct and immediate" standard, is now unstable following the Court's decision in Committee for Public Education v. Regan, 444 U.S. 646 (1980). In Regan, testing service assistance previously invalidated in Levitt $v$. Committee for Public Education, 413 U.S. 472 
include such ambiguously educational and health-related services as therapeutic, guidance, and remedial services for special students. ${ }^{50}$

\section{Excessive Entanglement}

The "excessive entanglement" requirement, as announced in Lemon $v$. Kurtoman ${ }^{51}$ has two distinct elements-administrative and political entanglement. Governmental administration or surveillance of the program within the religious institution must be minimal. Also, the program's involvement of religious institutions must not create a potential for "political division along religious lines."

The "excessive entanglement" requirement would appear to be the crucial obstacle for most Church-State partnerships in the social welfare field. Assuming that most social service programs lie outside of the restrictive education category, the "secular purpose" and "primary effect" requirements pose little difficulty. However, as Justice Blackmun noted, "if the answer to the 'primary effect' question seems easy, it serves to make the 'excessive entanglement' problem more difficult." Justice Blackmun's comment suggests that the "excessive entanglement" prohibition, when combined with the "primary effect" requirement, should have a scissor effect. ${ }^{54}$ As the legislature more scrupulously seeks to monitor the proper use of its funds, it concomitantly creates a greater entanglement with the institution's religious mission. For example, a legislature might wish to pay the cost of repair and maintenance of all private schools, including those with religious affiliations. If the legislature placed no further restraints on the program, the legislation would be invalid. ${ }^{55}$ To assure that the funds are used for secular purposes, the legislature might structure the program to reimburse schools for the cost of repairs performed on buildings used for secular functions and to require regular audits. The reimbursement and audit system is a safety measure that assures that the service will remain secular, yet it also creates excessive entanglement, since the audits require extensive surveillance of the schools' finances. In short, this legislature is damned if it does and damned if it doesn't. The addition of the "excessive entanglement" prohibition, therefore, in theory, would bar any Church-State partnership requiring more than arms-length dealing, regardless of how explicitly the funds were reserved for secular purposes.

This inherent scissor effect, however, is not fully taken into account in the Court's Establishment Clause analysis. To determine excessive entanglement the

(1973), under the direct and immediate test, was validated merely by having the state rather than the school prepare the testing service. Regan, thus, indicates that members of the Court have softened on the issue of direct assistance to parochial schools. See Committee for Pub. Educ. v. Regan, 444 U.S. at 665-66 (Blackmun, J., dissenting).

50. Wolman v. Walter, 433 U.S. at 244-48; Meek v. Pittenger, 421 U.S. at 371 .

51. 403 U.S. 602 (1971).

52. Lemon v. Kurtzman, 403 U.S. at 622.

53. Roemer v. Maryland Pub. Works Bd., 426 U.S. at 761-62.

54. See Choper, The Religion Clauses of the First Amendment: Reconciling the Conflict, 41 U. PITT. L. REv. 673, 680 (1980).

55. See Committee for Pub. Educ. v. Nyquist, 413 U.S. at 774-80. 
Court examines "the character and purpose of the institutions that are benefited, the nature of the aid that the State provides, and the resulting relationship between the government and religious authority." 56 These considerations are substantially the same ones used to determine primary effect under the second prong of the tripartite test. ${ }^{57}$ Consequently, the use of these criteria creates in the "excessive entanglement" inquiry the same two categories and two-tier standard of scrutiny found in the "primary effect" inquiry. When the aid is direct and the institution pervasively religious, the program's assistance violates either the "primary effect" or the "excessive entanglement" requirements. For example, the state may reimburse parents for the cost of public bus transportation to parochial schools, ${ }^{58}$ but may not directly reimburse the school for the cost of field trip transportation to centers of science or industry. ${ }^{59}$ The state may provide diagnostic education services off of the parochial school premises, ${ }^{60}$ but it may not provide the same on the premises. ${ }^{61}$ In each of these examples, the invalid assistance appears to violate both the "primary effect" and "excessive entanglement" requirements because aid which is "direct and immediate" is perforce excessively entangling. ${ }^{62}$ Thus, the inquiry into "excessive entanglement," though distinct in purpose, ferrets out no more violations of the Establishment Clause than does the inquiry into "primary effect." 63

The Lemon $v$. Kurtzman and Tilton $v$. Richardson decisions illustrate the restricted scope of the administrative entanglement criterion. In Lemon, state subsidization of secular courses taught in prviate elementary schools was invalidated when the Court concluded that extensive surveillance would be necessary to assure that the publicly funded courses remained secular. In Tilton, grants to religiously affiliated universities for construction of facilities were valid because minimal surveillance would be necessary to assure proper use of the buildings. The central inquiry in both cases was whether the benefits derived from the program could become a part of the institution's religious activities. The inquiry in Tilton yielded no violation because the universities, unlike parochial schools, were not pervasively religious and the students were less susceptible to proselytization. Tilton, then, helps to define the prohibition expressed in Lemon. Apparently, when the institution is pervasively religious, the assistance is direct, and the recipients are children susceptible to indoctrination, only excessive surveillance can provide the required assur-

56. Lemon v. Kurtzman, 403 U.S. at 615.

57. The similarity of considerations under both "primary effect" and "excessive entanglement" is evident in the Court's discussion of these two prongs in Tilton $v$. Richardson, 403 U.S. at 679-82, 684-88.

58. Everson v. Board of Educ., 330 U.S. I (1947).

59. Wolman v. Walter, 433 U.S. 229 (1977).

60. Id.

61. Meek v. Pittenger, 421 U.S. 349 (I975).

62. Cf. Choper, supra note 54, at 680-81. Professor Choper aligns the cases similarly, but attributes the apparent "conceptual chaos" only to the "entanglement" prong of the tripartite test.

63. Justices White and Rehnquist would eliminate the "excessive entanglement" inquiry because of this redundancy. Roemer v. Maryland Pub. Works Bd., 426 U.S. at 768-70. However, while the character of the institution and the nature of the aid are considered under both the "primary effect" and "excessive entanglement" requirements, they are considered for different purposes. Under "primary effect," they are used to determine the separability of the secular from the religious activities. Under "excessive entanglement," they are used to determine the need for surveillance of proper use. 
ance that there is no primarily religious effect. Consequently, social welfare programs which provide services from church buildings or church-related schools will find the entanglement prohibition a difficult obstacle to surmount. ${ }^{64}$

The political entanglement criterion has been described as a "warning signal," which suggests that it is merely probative of an Establishment Clause violation. ${ }^{65}$ Although political entanglement has been found only in programs promulgated at the local level by school boards, it does have application in the social services field. Recently, in Decker $v$. United States Department of Labor, ${ }^{66}$ the Court of Appeals for the Seventh Circuit held that the Comprehensive Employment Training Act of 1973 (CETA) violated the Establishment Clause by permitting the Catholic Church and its school system to receive funds for job training participants. A primary consideration was the political conflict fostered by a method of program funding which forced the government to select only those institutions which had the best chance of achieving the goals of the program. The program necessarily operated to the exclusion of less qualified religious institutions, thus forcing the government out of a position of neutrality toward all religions. Decker, thus, implicates all programs which are based on a competitive funding system as opposed to those which fund all nonprofit organizations neutrally, including sectarian institutions, which meet minimum standards.

\section{Government Regulation Under the Religion Clauses: The Dark Side of Church-State Partnerships}

Many Church-State partnerships, particularly those providing services within the general welfare services category, appear to be valid once the contours of the Establishment Clause are clarified. But as members of the Supreme Court have noted, sharing in the government largesse is not without its burdens. ${ }^{67}$ Government funding regulations limit the autonomy previously enjoyed by religious institutions. ${ }^{68}$ These restrictions can engender conflict in the partnership between the governmental policy behind the regulation and the institution's religious policies. Church-State partnerships initiated by the parties' mutual desire to provide social services present a dark side when religious beliefs begin to dictate how and to whom services will be provided. An important issue then arises as to what effect the institution's free exercise rights may have upon the terms of the Church-State partnership in the social services field.

A recent case involving Bob Jones University, which had religiously inspired

64. See, e.g., Decker v. United States Department of Labor Nos. 80-1230, 80-1231, and 80-1264 (7th Cir. Sept. 9, 1980), petition for rehearing en banc filed Oct. 14, 1980 (disqualification of parochial elementary and secondary schools from participation in the Comprehensive Employment Training Act work projects).

65. Committee for Pub. Educ. v. Nyquist, 413 U.S. at 797-98.

66. Nos. 80-1230, 80-1231, and 80-1264 (7th Cir. Sept. 9, 1980), petition for rehearing en banc filed Oct. 14, 1980.

67. See Tilton v. Richardson, 403 U.S. at 693-94 (Douglas, J., dissenting in part); Everson v. Board of Educ., 330 U.S. at 27 (Jackson, J., dissenting).

68. See text accompanying note 22 supra. 
policies of racial segregation, sheds light on the issue of free exercise rights in the face of government regulation. In Bob Jones University $v$. Roudebush, ${ }^{69}$ the Court of Appeals for the Fourth Circuit affirmed the district court's holding that Veterans Administration assistance to the university violated Title VI of the Civil Rights Act of 1964. Finding first that Veterans Adminstration assistance did not violate the Establishment Clause, ${ }^{70}$ the district court then held that the assistance was properly withheld without violating the university's free exercise rights. The court found that the government's policy against racial discrimination was compelling and that it outweighed the institution's religious beliefs which were only minimally deterred by the Title VI regulation against discrimination. Thus, the government's interests prevailed over the free exercise interests under the balancing test of Wisconsin $v$. Yoder. ${ }^{71}$ The Bob Jones University case indicates that the government can dictate the terms of the Church-State partnership when Congress has formulated a clear policy behind its regulation. ${ }^{72}$

The outcome of Bob Jones University is consistent with the theoretical relationship between the Religion Clauses. The value of preventing mutual entanglement between government and religious affairs occupies a central position within the relationship between the Establishment and Free Exercise Clauses. The Supreme Court has begun to use the idea of entanglement as a fulcrum to balance carefully the competing interests of the Religion Clauses. For example, the Court's concern for excessive entanglement prohibits most forms of direct assistance to parochial schools. ${ }^{73}$ In the instance of aid to parochial schools, entanglement thus becomes an obstacle. However, entanglement can also serve às a shield for parochial schools. In NLRB $v$. Bishop of Chicago, ${ }^{74}$ the Supreme Court held that the National Labor Relations Act did not confer jurisdiction over sectarian schools to the National Labor Relations Board. The Court's interpretation of the Act was clearly based on the consideration of entanglement with a pervasively religious institution. ${ }^{75}$ Entanglement, thus, is a concept which now cuts against both governmental and religious interests; it both deprives and protects religious institutions under the Religion Clauses.

If the entanglement prohibition applies consistently under both the Establishment and the Free Exercise Clauses, the social service provider receiving government assistance faces a dilemma of either assistance or noninterference. The Bishop

69. 529 F.2d 514 (4th Cir. 1975) (per curiam), affg, Bob Jones University v. Johnson, 396 F. Supp. 597 (D.S.C. 1974).

70. Bob Jones University v. Johnson, 396 F. Supp. at 605-06. Chief Justice Burger has also expressed opinion that the Supreme Court would find Veterans Administration assistance valid. See Committee for Pub. Educ. v. Nyquist, 413 U.S. at 804 (Burger, C. J., concurring in part and dissenting in part).

71. 406 U.S. 205 (1972).

72. See Bob Jones University v. United States, 639 F.2d 147 (4th Cir. 1980); Goldsboro Christian Schools v. United States, 436 F. Supp. 1314 (E.D.N.C. 1977); Green v. Connally, 330 F. Supp. 1150 (D.D.C.), affd per curiam sub nom. Coit v. Green, 404 U.S. 997 (1971). See also Note, Section 1981 After Runyon v. McCrary: The Free Exercise Right of Private Sectarian Schools to Deny Admissions to Blacks on Account of Race, 1977 DukE L. J. 1219.

73. See text accompanying notes 45-50 supra.

74. 440 U.S. 490 (1979).

75. Id., at 499-504. 
of Chicago case suggests that if a religious institution cannot receive assistance because of excessive entanglement, then the same institution should be exempt from burdensome regulation on the same grounds. ${ }^{76}$ When a religious institution participates in a social welfare program valid under the Establishment Clause, the converse of the proposition expressed in Bishop of Chicago is present: if the entanglement generated by the assistance and regulations does not violate the Establishment Clause, then the same regulations are not sufficiently entangling to warrant an exemption under the Free Exercise Clause. Thus, the religious institution receiving assistance may disable itself as an eligible participant in a social welfare program by claiming a cognizable free exercise right to be free of regulation accompanying the government assistance. The Establishment Clause permits the government to assist organizations to undertake only secular tasks. ${ }^{77} \mathrm{By}$ asserting its free exercise right, the organization perforce implies that the task it undertakes is no longer predominantly secular but predominantly religious. The assertion of a free exercise right magnifies the concern for entanglement under both the Free Exercise and Establishment Clauses. Consequently, the organization is faced with a choice: assistance with regulation or noninterference without assistance. ${ }^{78}$

Although the State need not accommodate the Church's free exercise interests in the Church-State partnership, it has done so in specific instances. ${ }^{79}$ As will be discussed in the following section, Congress has, for example, expressed a policy of not requiring denominational hospitals receiving assistance to perform abortion or sterilization procedures if such services are against the religious beliefs of the hospital's sponsors. This accommodation raises the counterpart issue to that previously discussed: to what extent may the government accommodate, rather than regulate, the Church as a participant in a social welfare program without violating the Establishment Clause? As will be discussed in the following section, Supreme Court decisions indicate that the Court will defer to a congressional policy of accommodation, despite apparent Establishment Clause entanglement. ${ }^{80}$

76. This proposition is not without qualification. The regulations and the assistance must be attendant to each other in order to assume that the degree of entanglement imposed by each is the same. The fact that the degree of entanglement between government and parochial schools created by the National Labor Relations Act would not necessarily be the same as that of public assistance to parochial schools is a major shortcoming of the Bishop of Chicago opinion.

77. Roemer v. Maryland Pub. Works Bd., 426 U.S. at 746

78. The religious institution is in a similar position to the Sabbatarian of Sherbert v. Verner, 374 U.S. 398 (1963), where the Court held that the Sabbatarian's free exercise rights were infringed by the government's policy of denying unemployment compensation benefits to persons unavailable for work on Saturdays. It is doubtful, however, that government regulation of social services could infringe upon a tenet as central to the institution's religion as that of the Sabbatarian in Sherbert. More importantly, the Court appears to distinguish valid accommodation to the free exercise rights of individuals from invalid accommodation to the free exercise rights of a class of persons when the resulting assistance would lead indirectly to benefits to sectarian institutions. Compare Thomas v. Review Bd., $101 \mathrm{~S}$. Ct. at 1433 (unemployment compensation for worker unemployed for religious reasons) with Committee for Pub. Educ. v. Nyquist, 413 U.S. at 788 (parent's claim of a free exercise right to assistance to send child to parochial school does not outweigh the Establishment Clause violation caused by the assistance).

79. The Church Amendment, 42 U.S.C. $\$ 300 \mathrm{a}-7$ (1976), accommodates the religious beliefs of denominational hospitals receiving funds under the Hill-Burton Program. See the Church Amendment, Part 2 of subsection A of Section III infra.

80. See Gillette v. United States, 401 U.S. 437 (1970) and see text accompanying notes 150-56 infra. 


\section{III}

\section{Hospital and Child Welfare Services Under the Religion Clauses}

This section considers the constitutionality of government programs that assist religious organizations providing hospital or adoption services. Each social service program creating a Church-State partnership can be expected also to create its own first amendment questions. Hospital and adoption services are discussed here because they highlight a few of the more difficult boundaries imposed by the Religion Clauses upon the social services field. Hospital Services will discuss two common forms of assistance in the social welfare field: reimbursements for services and construction grants. Also, this subsection will illustrate Congress' power to accommodate the religious interests of religious organizations participating in social service programs. Finally, Child Welfare Services will discuss the states' responsibilities to promote the religious upbringing of homeless children. The exigent circumstances of the social welfare field require the government to strike a delicate balance between the Religion Clauses when the recipient of the social service has religious interests warranting protection.

\section{A. Hospital Services}

Denominational hospitals ${ }^{81}$ receive substantial economic support from the federal and state governments. Economic support is initiated by assimilating a hospital into the community's certificate-of-need system. When a certificate-of-need is issued, facility expansion or modernization is authorized, and the hospital is, in effect, guaranteed a protected portion of the community's medical services market. ${ }^{82}$ The certificate-of-need also opens the door to financial assistance. Under the Hill-Burton Act, certified hospitals may receive funds for facility construction. ${ }^{83} \mathrm{~A}$ second form of direct assistance is provided by reimbursement for medical services authorized under the Medicare ${ }^{84}$ or Medicaid ${ }^{85}$ programs. Denominational hospitals also qualify for tax exemptions as charitable institutions. ${ }^{86}$

Denominational hospitals are a vital component of most cities' medical services system. Yet the modern Supreme Court has not considered the government's practice of assisting these religious institutions. In this subsection the constitutional-

81. "Denominational hospital" is a term used in this article to refer to all religiously affiliated hospitals. The strength of the affiliation between a hospital and its religion varies. Catholic-affiliated hospitals are owned by the Roman Catholic Church. In contrast, Jewish-affiliated hospitals are not owned by a religious organization; rather, Jewish members of the community are among the hospital's board of directors.

82. At least thirty-six states have certificate-of-need laws. Bovbjerg, Problems and Prospects for Health Planning: The Importance of Incentives, Standards, and Procedures in Certificate of Need, 1978 UTAH L. REV. 83. The economic effects of the certificate of need system are discussed in Symposium: Certificate of Need Law in Health Planning, 1978 UTAH L. REv. 1.

83. 42 U.S.C. $\$ \S 291-2910-1$ (1976).

84. 42 U.S.C. $\$ 1395(1976)$.

85. 42 U.S.C. $\S 1396(1976)$.

86. See, e.g., I.R.C. $\S 501$ (c)(3). Tax exempt status has been upheld for all religiously affiliated institutions. Walz v. Tax Comm'n, 397 U.S. 664 (1970). Cf. Bob Jones University v. United States, 639 F.2d 147 (4th Cir. 1980) (tax exempt status was denied because of racial policies). 
ity of denominational hospital support will be discussed. Finally, the Church Amendment, a measure permitting hospitals to enact anti-abortion policies based on religious convictions, will be discussed as an important illustration of Congress' authority within the limits of the first amendment to accommodate religious interests in a Church-State partnership.

1. The Constitutionality of Denominational Hospital Support. Bradfield $v$. Roberts is the only Supreme Court case which has considered an Establishment Clause challenge to government grants to denominational hospitals. ${ }^{87}$ However, because this case predates serious Establishment Clause analysis by nearly a half a century, Bradfield is a dubious precedent. Nonetheless, the Court has cited the Bradfield decision frequently and approvingly despite its limited analysis. ${ }^{88}$ Consequently, the Court's attitude toward Bradfield suggests that the issue is not whether hospital funding is valid but why and to what extent.

Tilton v. Richardson, rather than Bradfield, is perhaps the modern legal foundation for state aid to religious hospitals. Tilton is vital insofar as it liberates a large category of religious institutions not pervasively religious and serving people less susceptible to indoctrination from the strict standard of scrutiny applied to sectarian elementary schools. ${ }^{89}$ Denominational hospitals fit within the category of "not pervasively sectarian" institutions represented by Tilton's universities. ${ }^{90}$ And as the Court has recognized, health care, included in the general welfare services category, is an entirely secular service that it regards as being not convertible to religious ends. ${ }^{91}$ Thus, when considered in the abstract, assistance to denominational hospitals appears to be constitutional. ${ }^{92}$ So long as aid is adequately restricted to support for health services, the government may fund the hospital without danger of generating problems under the tripartite test.

87. See text accompanying notes 29-31 supra.

88. See, e.g., Roemer v. Maryland Pub. Works Bd., 426 U.S. at 746; Hunt v. McNair, 413 U.S. at 743; Lemon v. Kurtzman, 403 U.S. at 633 (Douglas, J., concurring).

89. See text accompanying notes 51-64 supra.

90. This assertion rests upon the two important assumptions that denominational hospitals do not reflect their religious mission and do not impose their religious values to an impermissible degree.

In light of the higher education cases, denominational hospitals need not "secularize" themselves to receive assistance. The federally funded buildings must remain free of religious symbols. See Tilton v. Richardson, 403 U.S. at 680 . However, the privately funded portions of the hospital may exhibit the hospital's religious affiliation. The exhibition of religions affiliation would become a problem only when the hospital would appear to have a pervasively religious character. The higher education cases, in particular Roemer, indicate that this threshold is quite high.

Denominational hospitals do not appear to discriminate in patient admissions according to religion. See Comment, Hospital Aid and the Establishment Clause: Conflict or Accommodation?, 13 UCLA L. REv. 1100,1116 (1966). The exhibition of religious affiliation and admissions policies appear to be two important factors in determining whether an institution has a "pervasively religious character." See Tilton v. Richardson, 403 U.S. at $680,686$.

91. Iemon v. Kurtzman, 403 U.S. at 616-17; Meek v. Pittenger, 421 U.S. at 364. Comments of the Court attendant to its citation of Bradfield $v$. Roberts also support this proposition. See text accompanying note 88 supra.

92. State courts have generally upheld government appropriations to denominational hospitals. See, e.g., Truitt v. Board of Pub. Works, 243 Md. 375, 221 A.2d 370 (1966); Abernathy v. City of Irvine, 355 S.W.2d 159 (Ky. 1961), cert. denied, 371 U.S. 831 (1962); Kentucky Bldg. Comm'n v. Effron, 310 Ky. 355, 220 S.W.2d 836 (1949); Craig v. Mercy Hospital-Street Memorial, 209 Miss. 427, 45 So. 2d 809 (1950). See also Gianella, supra note 20 , at 554-60. 
The two direct forms of assistance to hospitals, Hill-Burton construction grants and Medicare and Medicaid reimbursements, however, merit closer examination because they typify the forms of assistance received by religious institutions as social service providers.

The Hill-Burton program bears close resemblance in purpose and administration to the Higher Education Act of 1963 validated in Tilton. The most important factor which served to validate the construction grants in Tilton is present in the Hill-Burton program: the grant is for the construction of buildings restricted to secular uses. The Tilton Court expressed its belief that "one-time, single-purpose" construction grants require a minimal amount of surveillance to ensure proper use. ${ }^{93}$ This assumption is, as Justice Douglas emphasized, ${ }^{94}$ unpersuasive because merely a change in the subject of discussion in the classroom would convert the use of the building to a religious end. In the instance of Hill-Burton funding, the Court's assumption perhaps is more convincing. Hospitals must be designed for medical services, excluding other uses. Furthermore, hospitals are not as likely to be a place of organized religious activity as is a higher education institution. One anomaly within the parallelism between the Hill-Burton and Higher Education Acts is the Hill-Burton provision for a "retiring room" in general hospitals ${ }^{95}$ and chapel, altar, and offices for ecclesiastics in mental hospitals. ${ }^{96}$ In light of the nature of hospital services, these expenditures seem reasonable and justifiable. Frequently visitors or patients wish to pray, and the provision of a quiet room with no religious symbols, yet available for individual prayer or meditation, is a neutral means of accommodating this religious exercise. The disparity between a mere "retiring room" in a general hospital and a chapel in a mental hospital reflects the greater degree to which a patient's religious exercise may be burdened by extended confinement in a hospital for mental health treatment. ${ }^{97}$ If challenged, Congress' willingness to accommodate the possible free exercise right of a mental patient would receive deference from the Court. ${ }^{98}$

Reimbursements to denominational hospitals for medical services provided to Medicare $^{99}$ or Medicaid ${ }^{100}$ recipients are assistance possessing characteristics that

93. 403 U.S. at 688 .

94. Id., at 694 (Douglas, J., dissenting in part).

95. See 42 C.F.R. $\$ 53$ App. A, at 5918 (1947 Supp.).

96. See id., at 5928 .

97. Justice Brennan, in Abington v. Schempp, 374 U.S. at 230 (concurring opinion), suggests that legislatures can accommodate religious exercise in the face of apparent Establishment Clause violation. He mentions that a school could begin the day with a moment of silence, knowing that some will pray at that time. Abington v. Schempp, 374 U.S. at 281. Analogously, the hospital may have an open room, knowing that some will use it to pray. The state may provide chaplain services in prisons. Abington $v$. Schempp, 374 U.S. at 297. Analogously, the state may provide the same for persons confined to mental hospitals. See also Cruz v. Beto, 405 U.S. 319,322 n.2 (1972) (per curiam).

98. See text accompanying notes $150-56$ infra.

99. Medicare is a federal program of health insurance for the aged and disabled adopted in 1965 as part of the Social Security Act of 1935. The program is designed to provide basic protection against the costs of hospital and related post-hospital services for all persons over 65 entitled to retirement benefits under the Social Security Act or disabled persons under age 65 qualified under the Social Security Act. See 42 U.S.C. § 1395c (1976).

100. Medicaid is a federal program of medical assistance for the poor and medically needy adopted 
may permit its validation under a radically different Establishment Clause analysis. In his opinion in Nyquist, ${ }^{101}$ Chief Justice Burger suggests an analysis which would validate tuition grants to parents of parochial school children based on the idea that "government aid to individuals generally stands on an entirely different footing from direct aid to religious institutions." 102 For this proposition, Chief Justice Burger cites Everson ${ }^{103}$ and Board of Education v. Allen, ${ }^{104}$ instances of aid given to families rather than to schools; but he actually finds the source of his argument in the early religion case of Quick Bear v. Leupp. ${ }^{105}$ In Quick Bear, a decision long predating the Court's tripartite test, the Court upheld payments of funds held in trust for Indians of the Sioux tribe to a Catholic organization for education purposes. The court emphasized that the Sioux tribe owned the funds, and thus had full discretion over the use of the funds. ${ }^{106}$ Based on Quick Bear, Chief Justice Burger would hold that "where the state law is genuinely directed at enhancing a recognized freedom of individuals, even one involving both secular and religious consequences, . . . the Establishment Clause no longer has a prohibitive effect." 107

This argument, if understood correctly, proposes that the interposition of freedom of choice of an individual between the payment of funds by the government and the receipt of funds by religious institutions bars consideration by the Court of the effect of the funds under the Establishment Clause. In other words, the government is absolved of any responsibility under the Establishment Clause for the fact that funds find their way into the coffers of religious institutions if the funds were paid to the institution by the choice of the individual beneficiary. This argument gains strength when it is understood that by permitting individuals' free choice to direct funds the government remains neutral toward religious institutions. For example, the Federal Tax Code grants tax payers deductions for contributions to charitable organizations, ${ }^{108}$ a category which includes religious institutions. As recognized in Walz v. Tax Commission of New York City, ${ }^{109}$ the government remains in an acceptably neutral position when it accords religious institutions tax-exempt status, despite conferring economic benefit with favorable tax treatment. The charitable deduction provision would appear to stand on even more favorable ground under the Establishment Clause than the tax-exempt status provision. Not only is the government in a similarly neutral position toward religious institutions, but the

in 1965. It is financed by federal, state, and municipal funds and implemented pursuant to a state plan approved by the federal Department of Health and Human Services. See Bay Ridge Diagnostic Laboratory v. Dumpson, 400 F. Supp. 1104, 1105-06 (E.D.N.Y. 1975).

101. 413 U.S. 756 (1973).

102. Id., at 801 (Burger, C. J., concurring in part and dissenting in part).

103. 330 U.S. 1 (1947).

104. 392 U.S. 236 (1968).

105. 210 U.S. 50 (1908).

106. The basis for the Court's decision in Quick Bear is arguable. The majority opinion in Nyquist suggests that it is not based upon ownership of funds, but upon the free exercise rights of the Sioux tribe. See Committee for Pub. Educ. v. Nyquist, 413 U.S. at 781 n. 37.

107. 413 U.S. at 802 (Burger, C. J., concurring in part and dissenting in part).

108. I.R.C. $\$ 170$.

109. 397 U.S. 664 (1970). 
decision to contribute to the religious institution is governed by the choice of the taxpayer. Medicare, Medicaid, and most other reimbursements for social welfare services ${ }^{10}$ appear equally permissible under this analysis. By including all qualified denominational hospitals as medical service providers, the government remains neutral while leaving the personal choice ${ }^{111}$ of who provides the medical service to the Medicare or Medicaid recipient. ${ }^{112}$

The majority of the Court, however, has not accepted this "freedom of choice" argument. Rather, when funds originating from the government find their way into the treasury of religious institutions, the tripartite test applies. As indicated by the Nyquist decision, the Court views the distinction between grants and reimbursements, and direct and indirect payments, as simply one consideration which helps to determine whether religion is impermissibly advanced. Nevertheless, Medicare and Medicaid reimbursements would appear to have little difficulty under a formal application of the tripartite test. Medical benefits would come within the general welfare services category. The payments are in effect self-regulating because they are conditioned upon performance of a medical service authorized under the program. ${ }^{113}$ Under both Medicare and Medicaid, physical inspections and audits of the institution may be required. ${ }^{114}$ However, in light of the fact that denominational hospitals are not pervasively religious, the degree of entanglement imposed by such administrative procedures would not be excessive. ${ }^{115}$ To be sure, payments do go directly to the hospital's treasury without further restriction. Medicare and Medicaid funds, then, free other privately generated funds to be used by the hospital's religious sponsors for religious purposes. The Court, however, has expressly stated that this consideration, standing alone, is of no consequence under its Establishment Clause analysis. ${ }^{116}$

2. The Church Amendment: Accommodation of Denominational Hospitals in the Social Welfare Field. As previously discussed, compliance with the Establishment

110. Under Title XX of the Social Security Act, day care centers, including those with religious sponsors, may be reimbursed for the cost of providing services to qualified low income families. See 42 U.S.C. $\S 1397 \mathrm{a}(1976)$.

111. Both Medicare and Medicaid have explicit freedom of choice provisions. See 42 U.S.C. $\$ 1395 \mathrm{a}$ (1976); 42 U.S.C. $\$ 1396 a(a)(23)$ (1976).

112. As a final supportive note, in the recent decision, Thomas v. Review Board, the Supreme Court held that the state must pay workmen's compensation to a person unemployed because his religious beliefs prohibited work required by his former employer. Acknowledging serious Establishment Clause entanglement, the Court nevertheless ruled that the benefits must be provided to protect the individual's free exercise rights. Importantly, the Court suggested that assistance which promotes an individual's freedom stands on separate footing than assistance which is given to sectarian institutions. See Thomas v. Review Bd., $101 \mathrm{~S}$. Ct. at 1433. See also Americans United for Separation of Church and State v. Blanton, 434 U.S. 803 (1977), affg, 433 F. Supp. 97 (M.D. Tenr.) (three judge court) (validating assistance to students choosing to attend any accredited college).

113. Committee for Pub. Educ. v. Regan, 444 U.S. at 656-57 (reimbursements for cost of educational testing required by state adequately restricted to secular use).

114. See, e.g., 42 U.S.C. \$ 1396a (a)(26),(27), \& (30) (1976).

115. Committee for Pub. Educ. v. Regan, 444 U.S. at 661-62 (reimbursements for cost of educational testing required by state does not create excessive entanglement).

116. Roemer v. Maryland Pub. Works Bd., 426 U.S. at 747. 
Clause does not forbid the government to assist religiously affiliated hospitals in the specific and limited ways that it assists all health care providers. This conclusion, however, answers only half the question of what limitations the Establishment Clause imposes upon the Church-State partnership in the health care field. The other half concerns the limitations which the Constitution imposes upon the denominational hospital as a recipient of government funds. Assuming that the Establishment Clause does not forbid government assistance to denominational hospitals, the question remains as to whether such hospitals, hitherto private entities, may themselves become impressed with constitutional obligations as a consequence of their significant combination of government subsidies and their overall symbiosis with the government in the rendering of public services. ${ }^{117}$ And, if such hospitals do become subject to constitutional restraints, may the government attempt to accommodate the institution's religious interests which are in conflict with such restraints?

When denominational hospitals became recipients of Hill-Burton funds, they did not realize the extensive liabilities the funds could bring. In 1963, the Court of Appeals for the Fourth Circuit held in Simkins v. Moses H. Cone Memorial Hospital ${ }^{118}$ that the policies of a private hospital funded under the Hill-Burton program constituted "state action," invoking the right of equal protection under the fourteenth amendment. The precedent of the Moses Cone decision and others to follow placed denominational hospitals in a difficult position when the Supreme Court held in Roe $v$. Wade ${ }^{19}$ that the Due Process Clause included the liberty to seek an abortion. Patients denied abortions or sterilizations have initiated actions under 42 U.S.C. \& 1983, alleging that a denominational hospital's no abortion policy was a deprivation of their due process right under color of state law. In response to one such action, Taylor v. St. Vincent's Hospital, ${ }^{120}$ Congress passed the Church Amendment, a measure designed to permit denominational hospitals to enforce religioninspired policies against abortions:

(a) The Receipt of any grant, contract, loan, or loan guarantee under the Public Health Service Act, the Community Mental Health Centers Act, or the Developmental Disabilities Services and Facilities Construction Act by an individual or entity does not authorize any court or any public official or other public authority to require...

(2) Such entity to

(A) make its facilities available for the performance of any sterilization procedure or abortion if the performance of such procedure or abortion in such facilities is prohibited by the entity on the basis of religious beliefs or moral convictions. ${ }^{121}$

117. See, e.g., Burton v. Wilmington Parking Auth., 365 U.S. 715 (1961); Simkins v. Moses H. Cone Memorial Hosp., 323 F.2d 959 (4th Cir.), cert. denied, 376 U.S. 938 (1964). See generally Cronin, Private Hospitals that Receive Public Funds Under the Hill-Burton Program: The State Action Implications, 12 NEw ENGLAND L. REV. 525 (1977).

118. 323 F.2d 959 (4th Cir.), cert. denied, 376 U.S. 938 (1964).

119. 410 U.S. 113 (1973).

120. 369 F. Supp. 948 (D. Mont. 1973), affd, 523 F.2d 75 (9th Cir. 1975), cert. denied, 424 U.S. 948 (1976).

121. Health Programs Extension Act of 1973, § 401(b), 42 U.S.C. § 300a-7 (1976). 
The Church Amendment has two functions. First, the Secretary of Health and Human Services and the equivalent state officials are prohibited from requiring Hill-Burton grantees to perform abortions. Second, a hospital's status as a HillBurton grantee "does not authorize any court" to require the hospital to perform an abortion. The Congressional intent behind the Amendment's latter function is not clear. The ambiguity lies in the use of the language "does not authorize any court" as an instruction to the courts. As will be discussed, the Amendment can be interpreted either as an attempt to withdraw the power of federal courts to require Hill-Burton grantees to perform abortions or as a clarification of Congress' policy toward Hill-Burton grantees. Depending upon which of these interpretations is accepted, the Amendment raises several constitutional issues regarding the power of Congress (1) to restrict the jurisdiction of federal courts under 28 U.S.C. $\S$ $1343(3)$ to hear $\S 1983$ claims, (2) to limit the scope of the due process right to an abortion, and (3) to accommodate the religious interests of denominational hospitals.

a. Restriction of jurisdiction. In Chrisman v. Sisters of St. Joseph of Peace, ${ }^{122}$ the Court of Appeals for the Ninth Circuit held that the Church Amendment was a valid exercise of Congress' power to expand or restrict the jurisdiction of Article III federal courts. The Chrisman court interpreted the Amendment to prohibit the federal courts from "finding that a hospital which receives Hill-Burton funds is acting under color of state law." ${ }^{23}$ The jurisdiction of federal courts to hear a $\S 1983$ claim is based upon 28 U.S.C. $\S 1343$ which grants the district court original jurisdiction to redress the deprivation of any constitutional right under color of state law. Under the Chrisman interpretation, jurisdiction is restricted because the Amendment serves as a rule of law that the conduct of Hill-Burton grantees is not state action.

Ample legal precedent supports the Chrisman court's proposition that Congress has power to grant or revoke Article III jurisdiction. ${ }^{124}$ As the Supreme Court stated in Lockerty $v$. Phillips, ${ }^{125}$ "[t] $[$ he Congressional power to ordain and establish inferior courts includes the power 'of investing them with jurisdiction either limited, concurrent, or exclusive, and of withholding jurisdiction from them in the exact degrees and character which to Congress may seem proper for the public good." "126 The case of United States $v$ Klein ${ }^{127}$ indicates, however, that this power is not plenary; ${ }^{128}$ rather, it may not be used to invade proper judicial or executive functions. ${ }^{129}$

122. 506 F.2d 308 (9th Cir. 1974).

123. Id., at 310-311 (quoting Taylor v. St. Vincent's Hospital, 369 F. Supp. at 950).

124. See Kline v. Burke Construction Co., 260 U.S. 226 (1922); Sheldon v. Sill, 49 U.S. (8 How.) 440 (1850). But of. Battaglia v. General Motors Corp., 169 F.2d 254 (2d Cir.), cert. denied, 335 U.S. 887 (1948) (congressional control over federal jurisdiction subject to compliance with the requirements of the fifth amendment).

125. 319 U.S. $182(1943)$.

126. Id., at 187 .

127. 80 U.S. (13 Wall.) 128 (1871).

128. See Glidden Co. v. Zdanok, 370 U.S. 530, 567-68 (1962).

129. Yakus v. United States, 321 U.S. 414, 468 (1944) (Rutledge, J., dissenting). "It is one thing for Congress to withhold jurisdiction. It is entirely another to confer it and direct that it be exercised in a 
In Klein, the plaintiff, an administrator of an estate, sued in the United State Court of Claims for proceeds of the sale of the estate's property confiscated during the Civil War. The plaintiff's claim was based upon legislation creating a right of action for noncombatant rebel owners upon proof of loyalty. Earlier, the Supreme Court had held that a presidential pardon could serve as proof of loyalty. The plaintiff received judgment by producing a pardon. While the judgment was on appeal, Congress passed an act which ordered, first, that a pardon granted by the President is not admissible as proof of loyalty to sustain a claim, second, that any claim based upon a pardon shall be dismissed for want of jurisdiction, and third, that the Supreme Court shall dismiss for want of jurisdiction any claim pending on appeal based upon a pardon as proof of loyalty. ${ }^{130}$ Finding that the Act invaded the power of the President to grant the full effect of a pardon and the power of the Court to apply rules of decision, the Court held each of the provisions of the Act unconstitutional.

Klein is the only Supreme Court decision which has held unconstitutional a congressional regulation of a federal court's jurisdiction. ${ }^{131}$ As the opinion of Justice Chase stated, the Court would have upheld the Act as a proper exercise of Congress' Article III "exceptions" power ${ }^{132}$ if "it simply denied the right of appeal in a particular class of cases. . .."133 Instead, Congress had fragmented jurisdiction as "a means to an end": "to deny to pardons granted by the President the effect which this court had adjudged them to have." hold that "it is an unconstitutional invasion of the judicial function when Congress purports, not to withdraw jurisdiction completely, but to bind the Court to decide a case in accordance with a rule of law independently unconstitutional on other grounds." 135

Klein indicates that the Church Amendment would be unconstitutional if it is interpreted to be a restriction upon jurisdiction. Congress has prescribed a rule of law that a hospital that receives Hill-Burton funds does not act under color of state law, and thus, the federal courts are without jurisdiction under $\S 1343$. This rule of law is independently unconstitutional because it is contrary to Supreme Court decisions that indicate that state subsidization of private enterprises, such as Hill-

manner inconsistent with constitutional requirements or, what in some instances may be the same thing, without regard to them. . . This Congress cannot do. There are limits to the judicial power. Congress may impose others. And in some matters Congress or the President has final say under the Constitution. But whenever the judicial power is called into play, it is responsible directly to the fundamental law and no other authority can intervene to force or authorize the judical body to disregard it. The problem therefore is not solely one of individual right or due process of law. It is equally one of the separation and independence of the powers of government and of the constitutional integrity of the judicial process ...."Id.

130. United States v. Klein, 80 U.S, at 133-34.

131. But of. District of Columbia v. Eslin, 183 U.S. 62 (1901) (refusing to exercise jurisdiction possibly compelled by act of Congress).

132. U.S. Const. Art. III, §2.

133. United States v. Klein, 80 U.S. at 145 .

134. Id.

135. H. Hart \& H. Wechsler, The Federal Courts and the Federal Sistem 316 (1973). Justice Rutledge's dissent in Yakus v. United States supports this holding. See note 129 supra. 
Burton funding, is a factor which, when aggregated with others, may constitute state action. ${ }^{136}$

The Klein case, thus, poses a great obstacle to the Chrisman court's interpretation of the Amendment as a restriction of jurisdiction. In light of Klein and two other factors, the jurisdiction interpretation seems unwarranted. These factors instead point to an interpretation that the Church Amendment is no more than a statement of Congressional policy that Hill-Burton grantees are not required to perform abortions and that courts should not interpret Congress' policy to be otherwise. First, there is nothing in the language of the Amendment or in the legislative history which expressly states that Congress intends to tamper with Article III jurisdiction or with a finding of state action. ${ }^{137}$ Second, the Church Amendment applies to "any court," which would include not only Article III federal courts but state courts of general jurisdiction as well. Such an attempt to restrict the jurisdiction of state courts would be clearly in excess of congressional power. ${ }^{138}$ The interpretation of the Amendment as a statement of congressional policy, thus, seems easier and more reasonable. As will be discussed, it is, moreover, constitutional. An interpretation of the amendment as a restriction of jurisdiction, aside from its constitutional difficulties, requires one to read between the lines to find an intent to affect jurisdiction and findings of state action. Surely if Congress intended this meaning it would have expressed itself more clearly.

b. Scope of the Fifth Amendment due process right. An interpretation of the Amendment as a statement of Congress' policy that it does not require Hill-Burton grantees to perform abortions poses no constitutional difficulties. The right to an abortion as defined in Roe $v$. Wade has been significantly hemmed in by the later decisions of Maher $v . R o e^{139}$ and Poelker v. Doe. ${ }^{140}$ Poelker holds that even institutions that are unarguably governmental may deny abortion services without infringing upon the patient's due process right to an abortion. The Church Amendment is,

136. State action is determined by "shifting the facts and weighing circumstances." Burton v. Wilmington Parking Auth., 365 U.S. at 722 . Economic benefit is one element of a symbiotic relationship between government and private entity that may require a finding of state action. The Supreme Court has more recently set out a more restrictive doctrine of state action, requiring a nexus between the conduct challenged and the state. See Jackson v. Metropolitan Edison Co., 419 U.S. 345 (1974); Moose Lodge Number 107 v. Irvis, 407 U.S. 163 (1972). However, the Court has not declared that funding is no longer a fact to be considered in the state action determination. Direct subsidies pose special constitutional limitations outside of the state action question. See Norwood v. Harrison, 413 U.S. 455 (1973) (state subsidy of racially discriminatory school unconstitutional).

137. The legislative history of the Church Amendment is sparse. Although the history uses the terms "jurisdiction" and "state action" in describing Taylor $v$. St. Vincent's Hospital, it does not state that the amendment is designed to affect jurisdiction or a finding of state action. See H. R. Rep. No. 93-227, 93rd Cong., 2d Sess., reprinted in [1973] U.S. Code Cong. and Ad. News 1473, 1477.

138. See Cronin, supra note 117, at 571-72. Congress does have the authority to make federal jurisdiction over a matter exclusive, thus limiting directly the scope of the general jurisdiction of state courts. Bowles v. Willingham, 321 U.S. 503 (1944); The Moses Taylor, 71 U.S. (4 Wall.) 411 (1867). The Church Amendment, however, does not suggest an intent to make federal jurisdiction exclusive over such claims. Actions under $\S 1983$ may be brought in state courts of general jurisdiction. See, e.g., Maine v. Thiboutot, 448 U.S. 1 (1980).

139. 432 U.S. 464 (1977).

140. 432 U.S. 519 (1977). 
then, consistent with Poelker and does not restrict the scope of the patient's due process right to an abortion. ${ }^{141}$

c. Accommodation of religious interest. Assuming that the Amendment is valid as a statement of Congressional policy, the Amendment could still be challenged under the Establishment Clause. The Court of Appeals in Chrisman dismissed this challenge on grounds that the plaintiff failed to distinguish between "action taken to preserve the 'government's neutrality in the face of religious differences' and action which affirmatively prefers one religion over another." 142 The court reasoned that the government was maintaining its neutrality toward all denominational hospitals by permitting hospitals with religious anti-abortion policies to avoid using their facilities for abortion services. The Chrisman court likened this action to that of the Supreme Court in Sherbert $v$. Verner ${ }^{143}$ which required that Sabbatarians be given unemployment compensation benefits, despite not being available for work on Saturdays, just as other observant Christians are eligible for benefits, despite not being available on Sundays. Two important assumptions made in the court's Establishment Clause analysis warrant further consideration. First, the court assumed that the Supreme Court action in Sherbert in fact preserved neutrality. Second, it assumed that Congress is permitted to take the same actions to preserve the form of neutrality found in Sherbert as those the Supreme Court can take.

The term "neutrality" has developed two meanings in the context of Establishment Clause decisions. These meanings are illustrated by the Walz and Sherbert cases. In Walz, the inclusion of churches into the category of tax-exempt charitable institutions was valid because the government was neutral toward religious and nonreligious organizations. Neutrality of this sort occurs only when the category created is free of "religious gerrymanders."144 This form of neutrality may be described as "blind" neutrality because it permits religious organizations to be included within a category so long as they "fall within the natural perimeter" of that category. ${ }^{145}$ The Church Amendment arguably comes within this standard of neutrality if the "religious beliefs and moral convictions" category is interpreted to

141. The due process right, if infringed by the Church Amendment, would be a component of the fifth, rather than the fourteenth, amendment because the Church Amendment is a federal policy. The Amendment, however, does restrict the actions of state officials. To the extent which the Amendment pertains to the action of State officials, Congress is granted limited authority to act under section five of the fourteenth amendment. See Fullilove v. Klutznick, 448 U.S. 448, 477-85 (1980) (the Public Works Employment Act requiring a ten percent quota of minority business contractors is valid under section five of the fourteenth amendment insofar as it pertains to state or local grantees and valid under the fifth amendment as a means of exercising federal spending power). As Professor Cronin has observed, the Amendment could be interpreted as an exercise of Congress' power under section five to accommodate the free exercise rights of the hospital with the patient's due process rights. See Cronin, supra note 117, at 572-74. Nevertheless, the fifth amendment issue of the validity of the Church Amendment as a congressional policy would still remain and the Poelker decision resolves this issue in favor of the Church Amendment's validity.

142. Chrisman v. Sister of St. Joseph of Peace, 506 F.2d at 311.

143. 374 U.S. 398 (1962).

144. Walz v. Tax Comm'n, 397 U.S. at 696 (opinion of Harlan, J.).

145. Id. 
create a broad category based simply on conscience. ${ }^{146}$ If this interpretation is given, then religious beliefs could easily fall within this category of conscientious objection. Neutrality would be preserved, and no Establishment Clause problem is posed. ${ }^{147}$

The Chrisman court, however, preferred to interpret the Church Amendment as an effort to achieve neutrality among particular religions. This is the neutrality found in Sherbert and it is distinct from "blind" neutrality which treats religious and nonreligious entities alike. Describing the Supreme Court's actions in terms of "neutrality" was perhaps misleading. The remedy ordered in Sherbert places the state government in a more-than-neutral position toward Sabbatarians: an act of religious favoritism is required to arrive at this position of neutrality. ${ }^{148}$ Sherbert equally reveals favoritism because the remedy creates a situation where one is entitled to benefits if one's reason for not being available for work is religious, but one is not entitled to benefits if the reason is nonreligious. Similarly, under the Church Amendment, those denominational hospitals with anti-abortion religious beliefs will receive whatever protection is afforded by the policy, while those without such religious or moral beliefs will not receive such protection. ${ }^{149}$

A more appropriate term for this later form of neutrality is simply "accommodation." The Church Amendment, like the Supreme Court order in Sherbert, may be interpreted as action taken to accommodate the different religious interests of denominational hospitals. The Chrisman court's second assumption, then, is that Congress possesses the authority to take such action. The Supreme Court obviously can do so, as Sherbert and all other free exercise cases indicate. But Sherbert may not be used to validate similar actions of Congress. Congress' actions to accommodate religious beliefs raise serious Establishment Clause problems which the Supreme Court does not face. Actions taken to accommodate religious beliefs are undertaken for a religious purpose and have an effect of advancing religious interests. ${ }^{150}$ The interface between the Religion Clauses would appear to place limits on congressional power that the Supreme Court does not suffer, for it is only Congress that "shall make no law respecting an establishment of religion nor prohibiting the free exercise thereof." 151

The decisions of the Court in Welsh v. United States ${ }^{152}$ and Gillette v. United States ${ }^{153}$ indicate, however, that Congress does possess power to accommodate what it feels is a legitimate free exercise interest. A majority of the Court appears to support the position that the Court should defer to a judgment of Congress that religious beliefs should be specially protected even though the action effectively prefers the

146 The Church Amendment is described as a "conscience" clause. See H. R. Rep. No. 93-227, 93rd Cong., 2d Sess., reprinted in [1973] U.S. Code Cong. and Ad. News 1473, 1477.

147. The Amendment is, in this respect, similar to the conscientious objector provision of the Military Selective Service Act of 1967. See Gillette v. United States, 401 U.S. at 450-53.

148. In the recent Thomas $v$. Review Bd. decision, Justice Rehnquist points out that efforts undertaken strictly to accommodate religious interests perforce violate the Establishment Clause tripartite test.

101 S. Ct. at 1435-36 (Rehnquist, J., dissenting). See also Choper, supra note 54, at 685.

149. See Doe v. Charleston Area Medical Center, 529 F.2d 638 (4th Cir. 1975).

150. See note 148 supra.

151. U.S. Const. Amend. I.

152. 398 U.S. 333 (1970).

153. 401 U.S. 437 (1971). 
religious beliefs and thus violates the Establishment Clause. The Welsh and Gillette decisions raise this theory in the context of the conscientious objector exemption of the Military Selective Service Act of $1967^{154}$ for those opposed to war by reason of "religious training or belief." Relying on statutory interpretation, the Welsh majority avoided a constitutional decision. A dissent by Justice White, however, would have validated the exemption on ground of Congress' reasonable judgment that free exercise interests should be accommodated. Justice White would fashion a section five "enforcement by appropriate legislation" provision for the first amendment in the same way that the fourteenth amendment's section five operates:

But this Court is not alone in being obliged to construe the Constitution in the course of its work; nor does it even approach having a monopoly on the wisdom and insight appropriate to the task. . . If this was the course Congress took, then just as in Katzenbach $v$. Morgan . . . where we accepted the judgment of Congress as to what legislation was appropriate to enforce the Equal Protection Clause of the Fourteenth Amendment, here we should respect congressional judgment accommodating the Free Exercise Clause and the power to raise armies. ${ }^{155}$

The Gillette case subsequently forced the Supreme Court to consider the exemption under the Establishment Clause, and the deference to congressional judgment sought by the Welsh dissent was approved by the Gillette majority. ${ }^{156}$

The theory of Gillette, then, applies to the Church Amendment directly. The amendment is a response to what Congress perceives to be an infringement of denominational hospitals' free exercise rights. Deference to Congress' judgment will be accorded, ${ }^{157}$ and thus Congress has considerable leeway within the confines of the first amendment to accommodate the religious interests of religious organizations.

154. 50 U.S.C. App. $\$ 456(j)$ (1976).

155. 398 U.S. at $370-71$. Justice White's theory, however, does require abdication of power to ascertain and remedy free exercise rights which appears from the language of the Constitution to be granted solely to the Supreme Court. The lack of parallel structure between the first and fourteenth amendments reveals the stress that Justice White's interpretation imposes, for the fourteenth amendment has section five while the first amendment has the Establishment Clause. Section five permits Congress to remedy perceived violations of the fourteenth amendment. Fullilove v. Klutznick, $100 \mathrm{~S}$. Ct. 2758 (1980); Oregon v. Mitchell, 400 U.S. 112 (1970); Katzenbach v. Morgan, 384 U.S. 641 (1966). But the Establishment Clause precludes Congress from doing the same with perceived free exercise interests because to do so is to act with the purpose and effect of advancing that religious interest. To conveniently ignore the Establishment Clause presents the danger that Congress can "strengthen" or conceivably "dilute" free exercise interests which the Court would not hold to be cognizable under the first amendment. This reasoning is supported by the language of the first amendment that only Congress is prohibited from making a "law respecting the establishment of religion." By negative implication, only the Supreme Court possesses the authority to break the interlock of these clauses by protecting free exercise interests while simultaneously taking action which, if undertaken by Congress, would violate the Establishment Clause.

156. $40 \mathrm{l}$ U.S, at 453,460 . While approving congressional relief for religious beliefs, the Court acknowledged that previous decisions indicate that conscientious objectors do not have cognizable free exercise interests which would require judicial remedy under the first amendment. Id., at 461 n.23. Thus, the Court was permitting Congress to strengthen free exercise rights in the same manner that section five of the fourteenth amendment permits Congress to broaden equal protection and due process rights per Katzenbach $v$. Morgan.

This same theory has been applied in a limited fashion to free speech rights as well. See Columbia Broadcasting Systems v. Democratic National Comm., 412 U.S. 94, 103-04 (1973).

157. The Supreme Court has obliquely approved such conscience clauses. See Doe v. Bolton, 410 U.S. $179,197-98$ (1973). 


\section{B. Child Welfare Services}

The long term care of dependent and neglected children has traditionally been the province of private religious and nonsectarian child welfare organizations. ${ }^{158}$ State and local governments have responded to the increased need for child welfare services by becoming actively involved in the child welfare field. ${ }^{159}$ The state has undertaken both the financial and legal responsibilities of child welfare. When all legal ties between parent and child are severed-by abandonment or death of parent, for example-the state may order an adoption of the child by suitable and willing parents by virtue of the state's parens patriae authority. ${ }^{160}$ When the parents surrender only custody of their child-because of neglect, for example - the state will order a foster care or institutional placement until the child can be returned to her natural parents. ${ }^{161}$ To care for the child while a ward, the state may choose to establish its own foster care and adoption services, contract with private child welfare agencies, or do both. ${ }^{162}$

The first amendment issue concerning state support for private child welfare services derives from the state's efforts to recognize and protect the religious interests of its ward. Many states have a statutory requirement that the religious needs of the child be considered by the court as one factor in determining the proper foster care or adoption placement. ${ }^{163}$ To administer this policy, the state must ascertain first, if possible, the religious needs of the child. The state then assigns the child to a religious agency according to his religious preference. The agency attempts to place the child with foster care or adoptive parents whose religious beliefs and practices are compatible with that of the child. ${ }^{164}$ This statutory relationship between the state and religious child welfare agencies has been challenged under the Establishment Clause but has not been found unconstitutional. ${ }^{165}$

The first amendment issue posed by the religion-matching policy is whether the state's efforts to further the religious interests of its ward violates the Establishment Clause. The religion-matching policy is the result of the state's ambivalence toward its ward: the state, acting in loco parentis, desires to accommodate the free exercise

158. D. Schneider \& A. Deutsch, The History of Public Welfare in New York State-1867-1940, at 60-71, 158-179 (1941); N. Huggins, Protestants Against Poverty: Boston's Charities-1870-1900, at 83-110 (1971). S. Kamerman \& A. Kahn, Social Services in the United States: Policies and Programs 200-04 (1976); Pfeffer, Religion in the Upbringing of Children, 35 B.U.L. Rev. 333, 341-44 (1955).

159. Kamerman \& Kahn, supra note 158, at 221-26; Trattner, supra note 9, at 96-115.

160. See generally H. Clark, Domestic Relations $\$ \S 18.1-18.6$ (1968); A. Kadushin, Child WelFARE SERVices 434-516 (1967).

161. See generally Kadushin, supra note 160, at 354-433.

162. See generally KAMERMAN \& KAHN, supra note 158, at 253-99.

163. See Note, Religion Matching Statutes and Adoption, 51 N.Y.U.L. Rev. 262 (1976); Comment, A Reconsideration of the Religious Element in Adoption, 56 CoRnell L. Rev. 780 (1971); Note, Religion as a Factor in Adoption, Guardianship, and Custody, 54 Colum. L. Rev. 376 (1954); Annot., 48 A.L.R. 3d 383 (1973). See, e.g., Mass. Gen. Laws Ann. ch. 210, § 5B (Supp. 1980).

164. See Note, Religion Matching Statutes and Adoption, supra note 163, at 263-64

165. See Wilder v. Sugarman, 385 F. Supp. 1013 (S.D.N.Y. 1974); Petitions of Goldman, 331 Mass. 647, 121 N.E.2d 843, cert. denied, 348 U.S. 942 (1955); Dickens v. Ernesto, 30 N.Y.2d 61, 281 N.E.2d 153, 330 N.Y.S.2d 346, appeal dismissed, 407 U.S. 917 (1972). 
rights of the child, yet it must also maintain a separation of Church and State. The religion-matching policy thus exposes a "tension" between the Free Exercise and the Establishment Clauses. ${ }^{166}$ As discussed earlier with respect to the Church Amendment, ${ }^{167}$ the state may legitimately act to accommodate the religious beliefs of its citizens; however, a free exercise interest must be present to justify the religious advancement which results. ${ }^{168}$ This section will first consider the religionmatching policy in view of the requirements of the Establishment Clause. Because considerable Establishment Clause entanglement is evident, this section will then focus upon the free exercise rights of the child and parents to determine whether the resulting religious advancement is justified. Finally, this section will discuss the limitations imposed by the Establishment Clause upon both the state and the religious child welfare agency as they administer the religion-matching policy.

1. The Constitutionality of the Religion-Matching Policy. To determine whether the religion-matching policy violates the Establishment Clause, an analysis must consider its three requirements as promulgated by the Supreme Court: "secular purpose," "primary effect," and "excessive entanglement." Although the purpose of the religion-matching policy may be deemed secular because it promotes the temporal welfare of the state's wards, ${ }^{169}$ its principal effect may be to advance religion. Government foster care and adoption subsidies are not restricted to the "secular" care of the child; they support the total cost of care including the cost of the child's religious training. ${ }^{170}$ Under the religion-matching policy, the religious group which maintains the child welfare agency will keep its young follower, despite the permanent or temporary dissolution of the child's family. The policy, thus, assists the Church in retaining its members when they come under the care of the state, and consequently, religion is clearly advanced. ${ }^{171}$

A religion-matching policy may also create an entangling relationship between the state and the church-sponsored child welfare agencies. When the religious

166. This tension between the Religion Clauses was noted most recently by Justice Rehnquist with respect to government action in the social welfare field. See Thomas v. Review Bd., 101 S. Ct. at 1433-34 (Rehnquist, J., dissenting).

167. See Subsection A of Section 1II, supra.

168. See Thomas v. Review Bd., $101 \mathrm{~S}$. Ct. at 1436-37 (Rehnquist, J., dissenting); Gillette v. United States, 401 U.S. 437 (1971). See also Abington School Dist. v. Schempp, 374 U.S. at 296-98 (Brennan, J., concurring); Id., at 309 (Stewart, J., dissenting). See also text accompanying notes $150-55$ supra.

169. The religion-matching policy may be interpreted of course to have both a secular and religious purpose, since it was implemented to promote child welfare which in turn entails the promotion of the child's religion. See Wilder v. Sugarman, 385 F. Supp. at 1023-24. The Supreme Court, however, frequently avoids such an interpretation by deferring to the legislature's characterization of a statute's secular purpose. See, e.g., Committee for Pub. Educ. v. Nyquist, 413 U.S. at 773-74. See text accompanying notes $25-28$ supra.

170. Wilder v. Sugarman, 385 F. Supp. at 1024; Note, With the Best of Intentions: The Constitutionality of the Statutory Scheme for Voluntary Child-Care Agencies in New York, 4 N.Y.U. Rev. L. \& Soc. Change 21 , 27-28 (1974). Cf. Committee for Pub. Educ. v. Nyquist, 413 U.S. at 774-78; Levitt v. Committee for Pub. Educ., 413 U.S. at $479-82$ (in both cases funding programs with no restrictions on sectarian activities were held invalid).

171. See Comment, supra note 163, at 818-21; Comment, A Study of Religious Requirements for Adoption, 76 Dick. L. REv. 529, 540-46 (1972). 
organizations are employed by the state to administer services, the organizations take on government agency status. ${ }^{172}$ The government, therefore, must monitor the agency to ensure that it complies with the religion-matching statute and other government regulations. "Excessive" entanglement, however, is relative. If the government chose not to use religious agencies and yet retained the religion-matching policy, it would be forced to undertake the responsibilities formerly held by the religious agency. The government, then, would be required to make all inquiries into the religion of the child, natural parents, and the adoptive or foster parents. ${ }^{173}$ This assumes, however, that the state must use religion as a factor, yet it would appear that religion could be dropped as a criterion in placement altogether. ${ }^{174}$ The state may decide that the restrictions of the Establishment Clause preclude a religion-matching policy and that the religious needs of the child are not to be included as part of the placement determination. A public system would then completely avoid the possibility of entanglement. Consequently, entanglement, perhaps even to an "excessive" degree, occurs when the state chooses to contract with the religious agencies to carry out the child welfare work of the state.

In light of the considerable difficulties the religion-matching policy faces under the Establishment Clause, the state must justify its actions by furthering legitimate free exercise interests of either the child or natural parents. ${ }^{175}$ In the instance of a foster care placement, the legal ties between parent and child have not been severed; rather, only custody has been lost. ${ }^{176}$ In this case, religion-matching is justified as action furthering the free exercise rights of the natural parents who retain control over the religious upbringing of their child. ${ }^{177}$ In the instance of placement by adoption, however, the legal relationship between natural parent and child has been terminated. ${ }^{178}$ Consequently the state no longer has a legal basis for

172. Scott v. Family Ministries, 65 Cal. App. 3d 492, 506-07, 135 Cal. Rptr. 430, 438 (1976).

173. Wilder v. Sugarman, 385 F. Supp. at 1028-29.

174. A state ward would not appear to have a constitutional right to placement according to his religion, since placement without regard for religion would not necessarily inhibit the child's religious exercise. Moreover, a policy of placement without regard for religion does not place the government in such a non-neutral position as to require a court-ordered religion-matching policy to meet the "governmental obligation of neutrality in the face of religious differences." Sherbert v. Verner, 374 U.S. at 409. The State also has no constitutional obligation to provide child welfare services. See Wilder v. Sugarman, 385 F. Supp. at 1025.

175. See, e.g., Wilder v. Sugarman, 385 F. Supp. at 1024-25. See also Note, Religion Matching Statutes and Adoption, supra note 163, at 280-81. Cf. Bonjour v. Bonjour, 592 P.2d 1233, 1242-43 (Alaska 1979) (religion as factor in custody hearing violates Establishment Clause unless accompanied by finding that child has religious needs).

176. See Note, Legislative and Judicial Recognition of the Distinction Between Custody and Termination Orders in Child Neglect Cases, 7 . FAM. L. 66 (1967).

177. Pfeffer, supra note 158, at 348-57; Friedman, The Parental Right to Control the Religious Education of a Child, 29 Harv. L. Rev. 485 (1916). See also Wisconsin v. Yoder, 406 U.S. 205 (1972); Pierce v. Society of Sisters, 268 U.S. 510 (1925).

178. The right of adoption is a statutory creation transferring all parental rights of the natural parents to the adoptive parents. See, e.g., CaL. CIv. Code $\$ \S 228,229$ (West 1954). Parental authority may cease earlier, however, in a termination proceeding. See, e.g., Cal. Civ. Code $\$ 232$ (West Supp. 1981). See also Note, supra note 176 , at 66 .

The point at which parental authority of the natural parent ceases is important. If parental authority has not been terminated prior to the adoption proceeding, the natural parent, exercising her constitu- 
advancing the free exercise rights of the natural parents; and the issue then becomes whether the child, himself, has free exercise rights warranting protection by the state. The legitimacy of the child's free exercise rights is an issue that has received little attention by the courts. ${ }^{179}$ Nevertheless, the legal justification for religion-matching in adoption proceedings depends on the presence of identifiable religious interests of the child.

Judicially cognizable religious interests are present when the mature child is able to articulate her own religious beliefs and practices to the court. ${ }^{180}$ In order to protect these interests and to minimize conflict in the child's adoptive family, the state authorizes a private agency to match the religion of the child and the adoptive parents. The state could place the child without regard for religionmatching on the condition that the adoptive parents respect the child's free exercise rights. ${ }^{181}$ But this would be counter to the policy of advancing the best interests of the child. ${ }^{182} \mathrm{~A}$ placement which is compatible with a child's own religious interests may help to minimize the initial emotional trauma of his placement within a new family environment. ${ }^{183}$ This focus of acting in the religious interest of the child because it happens to be in his best temporal interest might also justify attention to religious habits or predispositions by a younger child clearly too young to express a free exercise right. ${ }^{184}$

tional right to control the religious upbringing of her child, may be able to affect the outcome of the adoption proceeding for or against the prospective adoptive parents. See 27 N.Y.U.L. REV. 848, 850 (1952); Ramsey, The Legal Imputation of Religion to an Infant in Adoption Proceedings, 34 N.Y.U.L. RE.V. 649, 661 (1959). If the parental authority has been terminated, the issue of the rights of the natural parent is separated from the qualifications of the adoptive parents. See Note, supra note 176, at 68.

179. See e.g., Petitions of Goldman, 331 Mass. 647, 652, 121 N.E.2d 843, 846 (1954) cert. denied, 348 U.S. 942 (1955) ("We do not attempt to discuss the philosophy underlying the concept that a child too young to understand any religion, even imperfectly, nevertheless may have a religion." Id.). See Comment, supra note 163 , at 809 .

180. See, e.g., Commonwealth ex rel. Bankert v. Children's Services, 224 Pa. Super. 556, 307 A.2d 411 (1973). Cf. Boerger v. Boerger, 26 N.J.Super. 90, 97 A.2d 419(1953); Weinman, The Trial Judge Awards Custody, 10 L. \& Contemp. Prob. 721 , 729 (1944) (both discussing the child's express preferences as a factor in the court's post-divorce custody determination). See also Wisconsin v. Yoder, 406 U.S. at 241-46 (Douglas, J., dissenting in part) (the court should inquire as to the preferences of the Amish children themselves in order to protect their free exercise rights).

181. See Comment, A Study of Religious Requirements for Adoption, supra note 171, at 548. See, e.g., Re Adoption of Maxwell, 4 N.Y.2d 429, 151 N.E.2d 848, 176 N.Y.S.2d 281 (1958). In Adoption of Maxwell, the court held that religion-matching was not a mandatory policy and that the wishes of the natural mother expressed serveral years after abandoning the child would not be fulfilled. While the court backed off from a mandatory religion-matching policy, the adoption order to the Maxwells stipulated that the child be baptized and educated as a Catholic as per the wishes of the natural mother despite the fact that the Maxwells were Protestant.

182. See Comment, supra note 163, at 808-09. Advancing the best interests of the child will also mean that religion-matching will not be stressed if matching requires a delay or a diminished possibility of adoption. Petition of Gally, 329 Mass. 143, 107 N.E.2d 21 (1952); In Re C., 63 Misc. 2d 1019, 314 N.Y.S.2d 255 (Fam. Ct. 1970).

183. See Pfeffer, supra note 158 , at $375,377$.

184. The court's primary goal is to facilitate the adjustment of the child in the new home. The court has broad powers in making the placement determination and therefore may consider a variety of factors that might smooth the transition. See Mnookin, Child Custody Adjudication: Judicial Functions in the Face of Indeterminacy, 39:3 L. \& Contemp. Prob. 226, 257-61 (1975). Cf. Bonjour v. Bonjour, 592 P.2d 1233, $1238 \mathrm{n} .10$ (Alaska 1979) (some courts may foreclose inquiry into religious beliefs as such, but they 
Frequently, very young children come before the court for adoption who have no knowledge of religion or ability to express a religious preference. Recognizing in this case the absence of any religious interests, states have taken one of two approaches with these children. Some states have a policy of dropping religionmatching as a part of the placement decision. ${ }^{185}$ This policy is consistent with Establishment Clause doctrine: there is no free exercise interest to protect, so dropping the religion-matching policy avoids an Establishment Clause violation.

In other states, the religion of the natural parents is imputed to the child. ${ }^{186}$ The State of New York, for example, requires by statute that the religious wishes of the natural parents be fulfilled whenever practicable in ordering an adoption placement. ${ }^{187}$ Such a policy raises a final constitutional issue of whether imputing the parent's religion is action which protects a legitimate free exercise interest of the child. Imputation of religion is often linked with the common law and constitutional right of parents to direct the religious upbringing of their child. ${ }^{188}$ The natural parent's free exercise rights in this matter are spurious, however. ${ }^{189}$ When the parental relationship with the child is terminated because of abuse, abandonment, or death, the natural parent's legal control and moral claims to the child's religious upbringing terminate as well. ${ }^{190}$ Consequently, imputation of religion is without basis if the end sought is advancement of the parent's free exercise rights.

Imputation of the parent's religion to the child to advance the child's free exercise rights would also appear to be without substance. The danger of imputation of religion is that it serves to advance religion as a status rather than as a free exercise right. Implicit in the Supreme Court's free exercise decisions is the principle that free exercise rights arise from belief and practices of religion, not from mere affiliation or cultural legacy. ${ }^{191}$ Since the young child does not practice

do not prohibit an examination of religious practice as affecting the child's temporal, mental, and moral welfare). Cf. Allison v. Owens, 4 Ariz.App. 496, 421 P.2d 929 (1966), cert. denied, 390 U.S. 988 (1968) (the court may take into consideration in the awarding of custody the church and Sunday school habits of the children and their divorced parents).

185. See, e.g., In Re Adoption of E, 112 N.J.Super. 326, 331, 271 A.2d 27, 30 (1970) ("In the present case $\mathrm{E}$ is of tender years. The decision of a child to form a belief or nonbelief in a Supreme Being must await the time when it has the maturity, understanding and independent volition to do so." Id.); MD. ANN. CODE art. 16, $\$ 67(\mathrm{~b})(1981)$. The statute provides that the court may place a child without regard to religion if it determines that the child "does not have sufficient religious background, training or beliefs to be a factor in the adoption. . ." Id. Cf. Bonjour v. Bonjour, 592 P.2d 1233, $1242 \mathrm{n}$. 20 (Alaska 1979); Wojnarowicz v. Wojnarowicz, 48 N.J.Super. 349, 137 A.2d 618 (1958) (children in custody hearings too young for the court to be able to ascertain religious needs).

186. See, e.g., Cal. Welf, \& INST. Code $\$ 11264$ (West 1980); Del. Code AnN. tit. 13, § 911 (1975); Mass. Gen. Laws Ann. ch. $210 \S 5$ B (West Supp. 1980); Pa. State Ann. tit. 1, 425 (Purdon Supp. 1979).

187. N.Y. Soc. Serv. LaW $\$ 373$ (McKinney 1976 and Supp. 1980).

188. $R e$ Adoption of Maxwell, 4 N.Y.2d at $438-39,15.1$ N.E.2d at 853,176 N.Y.S.2d at 288 (Desmond, J., dissenting); Note, Religion Matching Statutes and Adoption, note 163, at 280.

189. "[T]his device. . . is the legal imputation of religion to an infant by state action at the very moment the parental right ceases to exist, holding this religion fast for some subsequent moments in order to condition the forthcoming adoption by the religious factor. The religion of the child is thus not an extension of parental rights. It descends upon the child from the legal realm." Ramsay, supra note 178 , at 661 n.29.

190. Pfeffer, supra note 158, at 353; Comment, supra note 163 , at 823.

191. See Thomas v. Review Bd., 101 S. Ct. 1425 (1981); Welsh v. United States, 398 U.S. 333 
religion or hold religious beliefs, he is without free exercise rights until he reaches an age when religious belief may be held. ${ }^{192}$ Until the legitimate free exercise interests of the child are present, the state's imputation of the religious preferences of the parent merely protects religious status and perpetuates religion rather than religious rights. ${ }^{193}$

In conclusion, a religion-matching policy of the state and the practice of using religious child welfare agencies is justified in cases of foster care placement with parents of a religion consistent with the desires of the natural parents and of adoption when the child expresses a personal religious preference. The policy of imputing the religion of the parents to the child, however, has the effect of advancing religion without the justification of protection of a free exercise interest.

2. Establishment Clause Limitations on the Religion-Matching Policy. In light of this analysis, the Establishment Clause imposes limitations upon both the state and the religious adoption agency. The limitations become evident when it is understood that an Establishment Clause violation is averted only because the state or religious adoption agency is acting to further the child's free exercise rights. This tension between free exercise rights and the nonestablishment principle requires that the religion-matching policy be applied only when there is a religious interest of the child to be protected. Thus, the first and primary limitation is evident: the state may use the religion-matching policy to advance only the child's free exercise interests. From this initial limitation, others follow.

When the child has no legitimate free exercise interest, the state must ensure that religion as a qualification does not limit the range of prospective adoptive parents available to the child. In such instance, it is incumbent upon the state either to use its own adoptive agency to place the child or to use a private adoptive agency that has no religious qualifications for prospective adoptive parents.

Although the Establishment Clause applies directly only to the government, it

(1970); United States v. Seeger, 380 U.S. 163 (1965). See generally Note, Toward a Constitutional Definition of Religion, 91 HaRv. L. REv. 1056 (1978).

192. In Prince v. Massachusetts, the Supreme Court spoke of the "right of children to exercise their religion." Prince v. Massachusetts, 32 I U.S. 158, 165-66(1944). Prince and the decisions relied upon by the Prince opinion indicate, however, that a child's free exercise right is dependent upon the parent's rights asserted concurrently. See West Virginia State Bd. of Educ. v. Barnette, 319 U.S. 624, 630-31 (1943); Pierce v. Society of Sisters, 268 U.S. $510,534-35$ (1925); Meyer v. Nebraska, 262 U.S. 390,400 (1923). See also Wisconsin v. Yoder, 406 U.S. 205, 241 (1972) (Douglas, J., dissenting in part) (noting, with disapproval, the Court's subordination of the children's free exercise right to those of their parents).

Thus, it remains uncertain whether children may possess free exercise rights independently of their parents' rights. But assuming that they can, determining at what age these rights manifest is another difficult issue. State court decisions indicate that a child of a preschool age does not have sufficient intellectual and emotional development to have religious interests warranting consideration. See, e.g., Bonjour v. Bonjour, 592 P.2d 1233 (Alaska 1979); Wojnarowicz v. Wojnarowicz, 48 N.J.Super. 349,137 A.2d 618 (1958).

193. See Comment, supra note 163, at 813 \& n.168. But see, e.g., In Re Santos, 278 A.D. 373, 105 N.Y.S.2d 716 (1951). In In Re Santos, the court removed two children from the care of a Jewish children's agency and placed them with a Catholic one on the basis of evidence that the two children had been baptized Catholic by their natural mother. The court corrected the "mistake" of the original placement, emphasizing that "the children have a natural and legal right [to be raised Catholic] of 
serves also to limit indirectly the actions of the religious adoption agency. As one state court has held, the religious adoption agency's actions are "state action" for the purposes of the Establishment Clause because the child remains a state ward while in the agency's custody and the agency must act pursuant to the religionmatching statute. ${ }^{194}$ The religious adoption agency, like the government, may use religion as a qualification only when it is pursuant to the religion-matching policy. ${ }^{195}$ When the child has no free exercise interest, the agency that restricts its applicants to those of its own denomination causes the government to violate the Establishment Clause. But even if the child's religious preference is known, the agency would act improperly if it applies more restrictive religious qualifications than those necessary to match the child's religion. For example, if the agency placed its children only in homes of evangelists, the agency would act beyond the purposes of the religion-matching statute if a child it placed was not an evangelist, but merely Protestant. Such action would go beyond advancing the religious interests of the child. Since the government cannot take such action, the religious adoption agency as government agent is equally limited by the Establishment Clause.

\section{Conclusion}

The Church and State's harmony of purposes to help the needy is the premise of Church-State partnerships in the social welfare field. As Justice Blackmun stated in Roemer v. Maryland Board of Public Works: "It long has been established . . . that the State may send a cleric, indeed even a clerical order, to perform a wholly secular task." ${ }^{196}$ Like any aphorism, however, Justice Blackmun's comment is truthful yet beguiling. By the nature of the social welfare field, the first amendment creates limitations which run much deeper than Justice Blackmun's comment would suggest. The social welfare field was created by the work of the Church and other private charities. Today, social welfare programs are financed and thus dominated by all levels of government. The resulting Church-State partnership would seem valid so long as it undertakes only secular tasks. But, of course, the undertaking of social welfare services, valid in the abstract under the Establishment Clause, may prove difficult. Government regulations and the free exercise rights of the individual and the Church may conflict. Efforts to accommodate the religious interests of the individual welfare recipient may exceed the limitations of the Establishment Clause. Necessarily the tension between the Free Exercise and the Establishment Clauses will be tested as the Church and State work together to aid the individual in need.

which they cannot be deprived by their temporary exposure to the culture of another religion prior to the age of reason." Id., at 375, 105 N.Y.S.2d at 718 .

194. Scott v. Family Ministries, 65 Cal. App. 3d at 506-7, 135 Cal. Rptr. at 438.

195. Id., at 506, 135 Cal. Rptr. at 438 .

196. 426 U.S. at 746 (opinion of Blackmun, J.) 